Research Article

\title{
Optimal Design Method of a Hybrid CSP-PV Plant Based on Genetic Algorithm Considering the Operation Strategy
}

\author{
Rongrong Zhai $(\mathbb{D}$, Ying Chen, Hongtao Liu, Hao Wu, and Yongping Yang \\ School of Energy, Power and Mechanical Engineering, North China Electric Power University, Beijing 102206, China \\ Correspondence should be addressed to Rongrong Zhai; zhairongrong01@163.com
}

Received 1 May 2018; Revised 6 July 2018; Accepted 6 September 2018; Published 6 November 2018

Guest Editor: Mohammad O. Hamdan

Copyright ( 2018 Rongrong Zhai et al. This is an open access article distributed under the Creative Commons Attribution License, which permits unrestricted use, distribution, and reproduction in any medium, provided the original work is properly cited.

\begin{abstract}
Solar energy is the most abundant renewable energy and it has a great potential for development. There are two ways to transfer solar energy to electricity: photovoltaic power generation (PV) and concentrated solar power (CSP). CSP-PV hybrid system can be fully integrated with the advantages of the two systems to achieve low cost, stable output, and manageable to generate electricity. In this paper, the operation strategy of the CSP-PV system is proposed for parabolic trough CSP system and PV system which are now commercially operated. Genetic algorithm is used to optimize the design of the system and calculate PV-installed capacity, battery capacity, and storage capacity of CSP system, making the system to achieve the lowest cost of electricity generation. The results show that the introduction of the CSP system makes it possible to ensure the stability of the output power of hybrid system when the battery capacity is small, which greatly improves the annual utilization time of the PV and reduces solar abandonment. When the system is optimized by operation characteristics of Spring Equinox, the lowest LCOE is $0.0627 \$ / \mathrm{kWh}$, the rated capacity of PV and CSP system are $222.462 \mathrm{MW}$ and $30 \mathrm{MW}$, respectively, and the capacity of heat storage and battery are $356.562 \mathrm{MWh}$ and 14.687 MWh. When the system is optimized by the operation characteristics of the whole year, the lowest LCOE is 0.0555 $\$ / \mathrm{kWh}$, the rated capacity of PV and CSP system are $242.954 \mathrm{MW}$ and $30 \mathrm{MW}$, respectively, and the capacity of heat storage and battery are 136.059 MWh and 8.977 MWh. The comparison shows that the power generation curves of the hybrid system are similar in the two optimization-based methods-Spring Equinox based and annual based, but LCOE is lower when optimized by the annual operation characteristic, and the annual utilization rate of the system is higher when optimized by Spring Equinox based.
\end{abstract}

\section{Introduction}

Climate change and the scarcity of natural resources make the world to look for a cleaner and more efficient way to use energy to meet the growing energy needs. At present, renewable energy has a great potential and developed rapidly, and it will occupy an important share of future energy structure [1]. However, the major shortcomings of renewable energy are that their variability and intermittency can cause frequent imbalances and serious problems with the grid. The researchers have suggested that different strategies can be used to improve the safety and quality of energy supply, such as the use of more flexible thermal power plants [2], the introduction of appropriate energy storage equipment, and the use of multicomplementary strategy [3].
Solar energy is one of the most abundant renewable resources; solar radiation to reach the Earth's surface is 1800 times as the world's primary energy consumption [4]. There are two ways to convert solar energy into electricity: solar photovoltaic power generation and concentrated solar power [5]. The development of solar photovoltaic power generation is fast, and the ratio of installed solar photovoltaic will reach $16 \%$ of the global energy consumption [6]. The power generation costs of photovoltaic systems is relatively lower because of the low price of PV modules, and it can also be achieved grid parity in the absence of any market incentives [6]. However, the high price of photovoltaic energy storage system obstacles the further large-scale application of photovoltaic systems. Many scholars have focused on the concentrated solar power in the recent years; due to that, solar 
thermal system can be combined with the thermal storage system, so that the solar power plant can meet the requirements of grid operation and the peak load after the sun can still be deployed [7]. But due to the slow development of technology, the cost of solar thermal system is decreased lower than the solar photovoltaic system [8]. In this context, PV system and CSP system were initially considered to be competitors, but they are complementary in fact. The combination of the two technologies is increasingly concerned. PVCSP hybrid system is a viable way to generate power, and it can meet the local electricity demand and cost less than a single concentrated solar power [9]. The combination of solar photovoltaic power and solar thermal power can improve the capacity factor of the system and can be dispatched to meet the load demand of peak period [10]. The photovoltaic power is rich and cheap to meet the power load during the day; the peak load in the night will be met by solar thermal power system with storage. Then the stability and schedulability of the system can be ensured at low cost.

At present, a CSP-PV hybrid power system is being built in Ottana of Italy, the system is comprised of a $600 \mathrm{~kW}$ linear Fresnel concentrated solar power with $15 \mathrm{MWh}$ heat storage and a $400 \mathrm{~kW}$ photovoltaic system with $430 \mathrm{kWh}$ battery. Cocco et al. contrasted the two hybrid ways of the system, which are partially integrated and full-integrated, and found that the annual power generation and annual operating hours of the system on full-integrated were higher [11]. Cau et al. optimized the system's operational strategy by meteorological condition to maximize the annual power generation of the system while meeting the energy conservation and the minimum climbing time [12].

The CSP-PV hybrid system on the Atacama Desert in Chile coupled $20 \mathrm{MW}$ photovoltaic solar system and solar tower power system with $300 \mathrm{MWh}$ storage; the cost of power generation is lower than CSP-alone power system but higher than photovoltaic power system. The levelized cost of electricity (LCOE) in 2014 is 14.69 US cent/kWh and $13.88 \mathrm{cent} / \mathrm{kWh}$, respectively, based on Bluemap and Roadmap [9]. Capacity factor of typical intermittent energy is about $20 \%-40 \%$, this system can reach about $90 \%$ [12]. Green et al. proposed an operation with priority on the basis of this system; the priority of the output power is $50 \mathrm{MW}$, $100 \mathrm{MW}$, and $130 \mathrm{MW}$ [13]. Hlusiak et al. found that the collector has the greatest impact on the total cost, followed by coal prices; impacts of photovoltaic capacity and thermal storage system on the cost of power generation is relatively small; the cost of the CSP-PV hybrid system is $13 \%$ cheaper than the stand-alone concentrated solar power system with molten salt heat storage [14]. Bootello et al. divided power generation into three grades: the energy consumption of the tracking system, the energy consumption of the auxiliary equipment of the power plant and power generation connected to grid, and put forward the operation mode of the hybrid power station [15]. Larchet found that CSP-PV hybrid system with coal-fired backup unit has the lowest cost of electricity generation and project capital output. LCOE of this system is $42 \%$ and $52 \%$ lower than PV-alone system and PV-diesel hybrid system, respectively. CSP-PV hybrid system increased the investment but decrease the emission compared to coal-fired power system [16]. The combination of solar thermal and photovoltaic can provide stable energy and increase the capacity factor of the solar thermal power system. It not only can meet the basic requirement of the energy system but also can provide a low-risk investment option [17].

The research on CSP-PV hybrid system are mainly focused on the operation strategy and technical-economic analysis. But the research on the optimal configuration of CSP-PV hybrid system considering the operation strategy is few. In this study, the operation strategy of CSP-PV system is proposed for parabolic trough CSP system and PV system which are now commercially operated. Genetic algorithm is innovatively used to optimize the design of system and calculate PV installed capacity, battery capacity, and storage capacity of CSP system, making the system to achieve the lowest cost of electricity generation. The operation strategy proposed in this paper provides a new idea for the design and operation of CSP-PV hybrid power generation system. The optimization method can be used in the preliminary design of power station.

\section{System Description}

CSP-PV hybrid power system is composed of concentrated solar power system and photovoltaic system as shown in Figure 1. The upper dashed line box is the photovoltaic power generation subsystem, and the lower dashed box is the concentrated solar power subsystem. The PV power generation system includes PV array, inverter subsystem, and electronic storage system. The PV array consists of a number of subarrays, each of which consists of $20 \mathrm{PV}$ modules with a rated power of $250 \mathrm{~W}$. Each PV subarray is connected to the inverter to ensure that the DC will be converted into AC. At the same time, each inverter is equipped with a maximum power point tracking (MPPT) device to ensure that the photovoltaic subarray can run at the maximum power point. The PV modules are placed south and have a certain tilt angle, which maximizes the annual generation of photovoltaic power generation systems. The PV power generation technology is mature and the system is simple and has flexible layout and low operating costs. However, solar energy resources are fluctuating and intermittent, which makes the output power of photovoltaic power unstable, and it will have great impact on the power grid to a certain extent. To improve the stability of photovoltaic power output, the batteries are configurated.

The CSP system consists of trough collector subsystem, two tanks thermal storage subsystem, and power block subsystem. Heat transfer oil is used as heat transfer fluid, and molten salt is used as the heat storage medium. The inlet temperature of the heat transfer oil is $295^{\circ} \mathrm{C}$, and the outlet temperature is $395^{\circ} \mathrm{C}$. The feed water is heat by the heat transfer oil to become superheated steam and work in the steam turbine. When solar energy is sufficient, one part of the energy of the collector system is sent into the thermal cycle of power generation, another is storage by molten salt for power cycle when the solar energy is poor. When the stored energy is used out, the gas backup can be started to meet the required load. The concentrated solar power system 


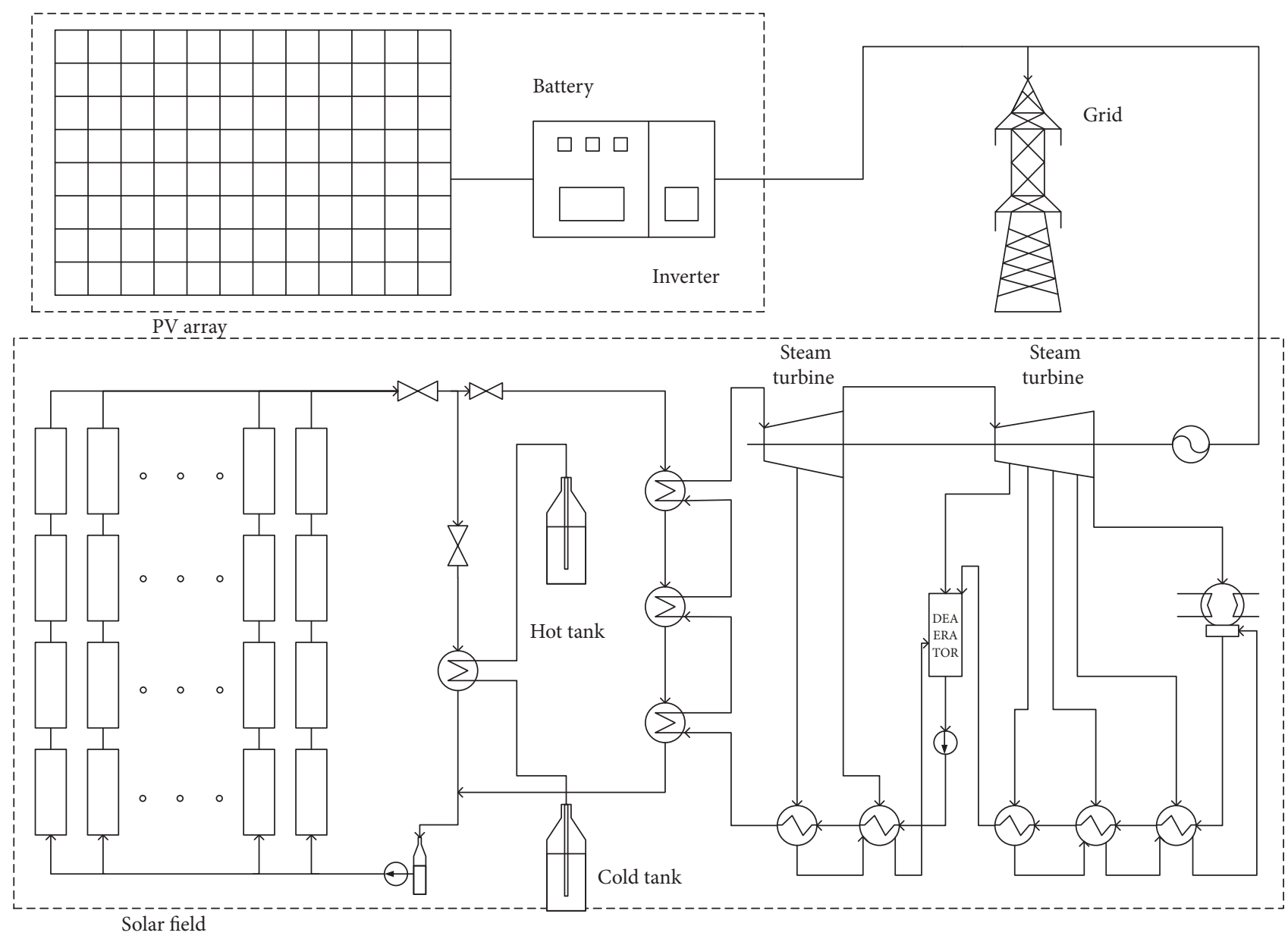

FIGURE 1: CSP-PV hybrid power system.

adopts the energy conversion form of light-heat-electricity, in which the thermal delay of the system and the heat storage system makes the output power of the concentrated solar power system stable, reduce fluctuation of solar energy, and improve the manageability of renewable energy. Therefore, it is expected that a low-cost manageable output solar power generation system will be established by coupling a low-cost photovoltaic power generation system with a concentrated solar power system that can be used for peaking.

The main parameters that affect the energy and economic performance of the system are the collector field area, the storage capacity, the Rankine cycle power, the PV-installed capacity, and the capacity of the battery. In this paper, based on the $30 \mathrm{MW}$ CSP system, the storage capacity, the PVinstalled capacity, and the capacity of the battery are selected as the optimization objects to make the power generation cost of the system minimal.

The main parameters of power block in the design condition are shown in Table 1.

\section{Model Establishment}

Performance analysis of CSP-PV hybrid power system is realized in software Matlab [18]. The simulation model has been simplified. The collector field area, the heat storage
TABLE 1: Main parameters of power block.

\begin{tabular}{lccc}
\hline & $\begin{array}{c}\text { Pressure } \\
(\mathrm{MPa})\end{array}$ & $\begin{array}{c}\text { Temperature } \\
\left({ }^{\circ} \mathrm{C}\right)\end{array}$ & $\begin{array}{c}\text { Mass flow } \\
(\mathrm{kg} / \mathrm{s})\end{array}$ \\
\hline $\begin{array}{l}\text { Main steam } \\
\begin{array}{l}\text { The first extraction } \\
\text { The second } \\
\text { extraction }\end{array}\end{array}$ & 9.80 & 369.41 & 55.8 \\
$\begin{array}{l}\text { The third } \\
\text { extraction }\end{array}$ & 1.70 & 257.59 & 6.8 \\
$\begin{array}{l}\text { The fourth } \\
\text { extraction }\end{array}$ & 0.60 & 250.55 & 4.4 \\
$\begin{array}{l}\text { The fifth } \\
\text { extraction }\end{array}$ & 0.25 & 163.75 & 1.9 \\
$\begin{array}{l}\text { The sixth } \\
\text { extraction }\end{array}$ & 0.12 & 104.78 & 1.4 \\
\begin{tabular}{l} 
Exhaust steam \\
\hline
\end{tabular} & 0.008 & 85.93 & 2.6 \\
\hline
\end{tabular}

capacity, the Rankine cycle power, the PV-installed capacity, and the capacity of the battery are the main design parameters that affect the system performance. The design of the system is optimized in order to find the system structure with the lowest cost of power generation under 


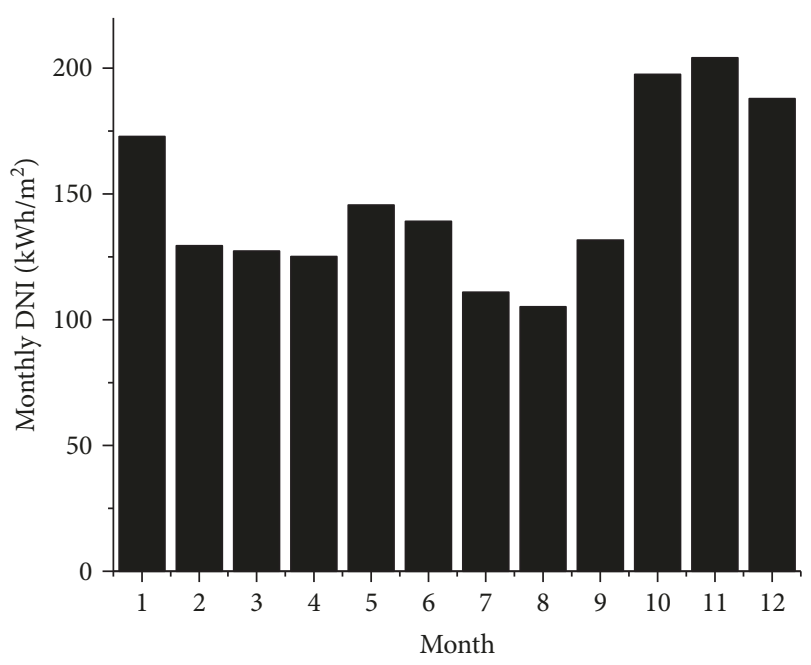

FIgURE 2: Monthly DNI of Lhasa.

the constraints of energy balance and storage energy. The CSP-PV hybrid system model includes the photovoltaic subsystem model and the solar thermal subsystem model. The input parameters of the model are the meteorological data of a certain location.

3.1. Solar Energy Resources. In this paper, the database of a typical meteorological year is from SAM software [19] and Lhasa $\left(91.13^{\circ} \mathrm{E} 29.67^{\circ} \mathrm{N}\right)$ is selected. In this paper, the database of a typical meteorological year is from NREL [20]. The meteorological data include direct normal irradiation (DNI), global horizontal irradiance (GHI), ambient temperature, and wind speed.

Annual DNI and GHI of Lhasa are $1777 \mathrm{kWh} / \mathrm{m}^{2}$ and $1818 \mathrm{kWh} / \mathrm{m}^{2}$, respectively. In Lhasa, the annual variation of GHI is small and the radiation intensity is large, but DNI varies greatly with season changes and the radiation intensity of autumn and winter is higher than that of summer. The variation of solar radiation intensity makes the performance of the system change greatly. Monthly DNI of Lhasa is shown in Figure 2.

3.2. PV Subsystem Model. The PV system model consists of photovoltaic panels which output is rated at $250 \mathrm{~W}$. PV panels are placed at a fixed angle and faced south. According to the equation proposed by Duffle, the effect of PV module temperature change on the power generation performance of the system is considered.

The main parameters of PV panels are shown in Table 2. The operating temperature $\left(T_{C}\right)$ of $\mathrm{PV}$ panels is determined by the rated operating temperature of $\mathrm{PV}$ panels (equation (1)).

$$
T_{C}=T_{A}+\left(T_{\mathrm{NOCT}}-T_{A, \mathrm{NOCT}}\right) \frac{\mathrm{GI}}{\mathrm{GI}_{\mathrm{NOCT}}} \frac{U_{L, \mathrm{NOCT}}}{U_{L}}\left[1-\frac{\eta_{\mathrm{PV}}}{\tau \alpha}\right],
$$

where $T_{A}$ is the ambient temperature; the ambient temperatures for nominal operating cell temperature $\left(T_{A, \mathrm{NOCT}}\right)$ is $20{ }^{\circ} \mathrm{C}$; the solar radiation $\left(\mathrm{GI}_{\mathrm{NOCT}}\right)$ is $800 \mathrm{~W} /$
TABLE 2: Main parameters of PV module.

\begin{tabular}{lccc}
\hline PV module & \multicolumn{3}{c}{ Other assumptions } \\
\hline $\begin{array}{l}\text { Solar cell } \\
\text { technology }\end{array}$ & Polycrystalline & Derating factor $f_{\mathrm{PV}}$ & 0.8 \\
$\begin{array}{l}\text { Nominal } \\
\text { power }\end{array}$ & $250 \mathrm{~W}$ & $U_{L, \mathrm{NOCT}}$ & 9.5 \\
$P_{\mathrm{PV}, \mathrm{REF}}$ & & & \\
$\begin{array}{l}\text { Nominal } \\
\text { efficiency }\end{array}$ & $14.9 \%$ & $U_{L}$ & $5.7+3.8 \mathrm{~V}_{\text {wind }}$ \\
$\eta_{\mathrm{PV}, \mathrm{NOM}}$ & \multicolumn{4}{c}{0.8} \\
$\begin{array}{l}\text { Nominal } \\
\text { operating cell }\end{array}$ & $46^{\circ} \mathrm{C}$ & $\begin{array}{c}\text { Transmittance- } \\
\text { absorptance } \\
\text { temperature } \\
T_{\mathrm{NOCT}}\end{array}$ & \multicolumn{3}{c}{ coeff. $(\tau \alpha)$} \\
$\begin{array}{l}\text { Active panel } \\
\text { area } A_{\mathrm{MOD}}\end{array}$ & $1.675 \mathrm{~m}^{2}$ & $\begin{array}{c}\text { Inverter nominal } \\
\text { efficiency }\end{array}$ \\
$\begin{array}{l}\text { Temperature } \\
\text { coeff. of } \\
\text { power } \gamma\end{array}$ & $-0.41 \% / \mathrm{K}$ & $\begin{array}{c}\text { Nominal global } \\
\text { irradiance GI }\end{array}$ & $97.8 \%$ \\
\hline
\end{tabular}

$\mathrm{m}^{2} ; U_{L}$ and $U_{L, \text { NOCT }}$ is the actual and rated heat transfer factor; $\eta_{\mathrm{PV}}$ is the actual PV panel efficiency, which can be calculated by equation (2). $\tau \alpha$ is the transfer absorption factor [21]. The efficiency of PV panels

$$
\eta_{\mathrm{PV}}=\eta_{\mathrm{PV}, \mathrm{NOM}}\left[1+\gamma\left(T_{C}-T_{C, \mathrm{REF}}\right)\right]
$$

where $\eta_{\mathrm{PV}, \mathrm{NOM}}$ is the nominal efficiency; $\gamma$ is the temperature factor; $T_{C, \mathrm{REF}}$ is the $\mathrm{PV}$ module temperature under standard test conditions $\left(25^{\circ} \mathrm{C}\right)$.

$$
P_{\mathrm{PV}}=n_{\mathrm{MOD}} A_{\mathrm{MOD}} G I \eta_{\mathrm{PV}} \eta_{\mathrm{INV}} f_{\mathrm{PV}}
$$

The output power of PV panels can be calculated using equation (3). Where $n_{\mathrm{MOD}}$ is the number of PV subarray; $A_{\mathrm{MOD}}$ is the active area of each PV module, and $\eta_{\mathrm{INV}}$ is the inverter efficiency. A derating factor $f_{\mathrm{PV}}$ is finally considered to account for soiling of the panels, wiring losses, shading, snow cover, aging, and other secondary losses.

The use of batteries can make up for difference between PV power generation and energy demand. The energy available for the battery can be described as the charge state "SOC ${ }_{B}$ ", which is the ratio of the stored energy to the rated storage capacity. The battery model can be calculated by the following formula. Where $\eta_{\mathrm{BC}}$ and $\eta_{\mathrm{BD}}$ are the battery efficiencies during charge and discharge processes, respectively. Battery efficiency depends on several operating parameters such as current, SOC, charging and discharging power, and battery lifetime. To simplify the model, a constant efficiency of $94 \%$ is assumed as declared by the manufacturer while a nominal Depth-of-discharge (DOD) of $80 \%$ is considered (with a minimum SOC of $10 \%$ and a maximum SOC of $90 \%$ ).

$$
\operatorname{SOC}_{B}(t)=\operatorname{SOC}_{B}(t-1)+\frac{\left(P_{\mathrm{BC}} \eta_{\mathrm{BC}}-\left(P_{\mathrm{BD}} / \eta_{\mathrm{BD}}\right)\right) \Delta t}{E_{B}} .
$$


TABLE 3: Main parameters of CSP module.

\begin{tabular}{lccc}
\hline Design condition & & Optical coefficient & 0.98 \\
DNI & $800 \mathrm{~W} / \mathrm{m}^{2}$ & $\begin{array}{c}\text { Reflectance efficiency } \\
\text { Cleanliness factor }\end{array}$ & 0.93 \\
Ambient temperature & $3^{\circ} \mathrm{C}$ & 0.95 \\
Trough collector & & Tracking factor & 0.99 \\
Focal length & $1.84 \mathrm{~m}$ & Dust cover coefficient & 0.98 \\
Width & $5 \mathrm{~m}$ & End shadow coefficient & 0.97 \\
Unit length & $8 \mathrm{~m}$ & Transmissivity factor & 0.96 \\
Oil inlet/outlet & $285 / 390^{\circ} \mathrm{C}$ & Coating & absorption factor \\
temp. & \multicolumn{3}{c}{0.95} \\
& \multicolumn{3}{c}{ Other factor } \\
\hline
\end{tabular}

The PV model is established based on the literature [22]. Rated output power is $30000 \mathrm{~kW}$. The annual power generation of Matlab model is $130690 \mathrm{MWh}$. The plant electricity rate is defined as the electricity consumed by the power plant itself divided by the gross electricity produced by the power plant. The plant electricity rate is assumed as $2.43 \%$ according to statistics of Chinese power generation, then the actual power generation is $127514 \mathrm{MWh}$. The annual power generation of SAM is $122179 \mathrm{MWh}$, and the deviation of annual power generation is $4.18 \%$. The reason for the higher power generation in Matlab is that the model ignores few losses of the actual power generation process.

3.3. CSP Subsystem Model. The simulation of the CSP generation system is based on the parameters of the $30 \mathrm{MW}$ SEGS VI CSP plant.

The solar input is determined by equation (5):

$$
\begin{aligned}
Q_{\text {solar }}= & \mathrm{DNI} \cdot A_{\text {net }} \cdot \mathrm{KIA} \cdot f_{\text {opt }} \cdot f_{\text {ref }} \cdot f_{\text {trac }} \cdot f_{\text {end }} \cdot f_{\text {clean }} \\
& \cdot f_{\text {dust }} \cdot f_{\text {tran }} \cdot f_{\text {abs }},
\end{aligned}
$$

where $A_{\text {net }}$ is the net aperture area of parabolic trough collector, KIA is incident angle correction, $f_{\text {opt }}$ is the optical
TABLE 4: Physical property of solar salt.

\begin{tabular}{lccc}
\hline Melting point & $220^{\circ} \mathrm{C}$ & Viscosity & $1.776 \mathrm{cP}$ \\
\hline $\begin{array}{l}\text { Ceiling } \\
\text { temperature }\end{array}$ & $600^{\circ} \mathrm{C}$ & $\begin{array}{c}\text { Thermal } \\
\text { conductivity } \\
\text { Thermal }\end{array}$ & $0.519 \mathrm{~W} /(\mathrm{m} \cdot \mathrm{K})$ \\
$\begin{array}{l}\text { Surface } \\
\text { tension }\end{array}$ & $109.2 \mathrm{mN} / \mathrm{m}$ & $\begin{array}{l}\text { Thacity } \\
\text { capacion }\end{array}$ & $1495 \mathrm{~J} / \mathrm{kg} \cdot \mathrm{K})$ \\
Density & $1837 \mathrm{~kg} / \mathrm{m}^{3}$ & $\begin{array}{c}\text { Fusion heat } \\
161 \mathrm{~kJ} / \mathrm{kg}\end{array}$ \\
\hline
\end{tabular}

coefficient, $f_{\text {ref }}$ is the reflectance efficiency, $f_{\text {trac }}$ is the tracking factor, $f_{\text {end }}$ is the coefficient to correct end loss effects, $f_{\text {clean }}$ is the factor to correct for actual mirror cleanliness, $f_{\text {dust }}$ is the factor to correct for dust cover, $f_{\text {tran }}$ is the transmissivity factor, and $f_{\text {abs }}$ is the coating absorption factor.

The main parameters of the CSP station are shown in Table 3 [22]. The hourly operating characteristics analysis of CSP system is based on the meteorological conditions, especially solar radiation and solar location. The heat loss of the collector field is taken into account. The Equinox day of Lhasa, annual average DNI, and annual average temperature is selected as the system design point.

LS-2 collector tube is used as solar collectors, and the row space is $15 \mathrm{~m}$. The heat loss of the collector is affected by DNI, flow of heat transfer oil, ambient temperature, and wind speed. Usually, the impact of wind speed on heat loss can be ignored.

The available heat input depends on the solar heat input, the thermal losses of the receivers, and the field piping, as shown in equations (6) and (7) [23], where $T_{\mathrm{i}}$ and $T_{\mathrm{O}}$ are the inlet and outlet temperature of the heat transfer oil. The heat pipe is composed of a loop, and each circuit is connected through a pipe. The heat loss on the pipe is obtained from the empirical formula (8) [23], where $\Delta T$ is the temperature difference between the average temperature of the collector field and the ambient temperature.

$$
\begin{aligned}
Q_{\text {avail }} & =Q_{\text {solar }}-Q_{\text {collloss }}-Q_{\text {pipe }}, \\
Q_{\text {col, loss }} & =\frac{a_{0}\left(T_{0}-T_{i}\right)+\left(a_{1} / 2\right)\left(T_{0}{ }^{2}-T_{i}{ }^{2}\right)+\left(a_{2} / 3\right)\left(T_{0}{ }^{3}-T_{i}{ }^{3}\right)+\left(a_{3} / 4\right)\left(T_{0}{ }^{4}-T_{i}^{4}\right)}{T_{0}-T_{i}}+\frac{\mathrm{DNI}\left[b_{0}\left(T_{0}-T_{i}\right)+\left(b_{1} / 3\right)\left(T_{0}{ }^{3}-T_{i}{ }^{3}\right)\right]}{T_{0}-T_{i}}, \\
Q_{\text {pipe }} & =0.01693 \Delta T-0.0001683 \Delta T^{2}+6.78 \times 10^{-7} \Delta T^{3} .
\end{aligned}
$$

The heat storage medium of CSP system is binary molten salt, which composes of $60 \% \mathrm{NaNO}_{3}$ and $40 \%$ $\mathrm{KNO}_{3}$, and the physical properties are shown in Table 4 [24]. The available energy of the heat storage is obtained by the energy balance of the collector field, the power block, and the heat loss. In this paper, the heat loss of the thermal storage tank is assumed to be $2 \%$. The thermal oil VP-1 is used for heat transfer fluid, which has a wide optimum use range of $12^{\circ}$ to $400^{\circ} \mathrm{C}$.
The solar thermal energy absorbed by the collectors is stored in the thermal storage system as thermal energy. When the power output from CSP subsystem is needed, the molten salt releases heat and water is heated and turned into steam, making the turbine work. The turbine efficiency is variable and related to the steam mass flow in the offdesign condition. Variation of turbine efficiency under offdesign conditions is considered in power block model. The reduction rate in turbine efficiency can be calculated using 
equation (9) [25], then turbine efficiency can be calculated using equation (10). The generator efficiency can be calculated using equation (11) [26].

$$
\begin{aligned}
\text { Reduction rate } & =0.191-0.409 \frac{m}{m_{\text {ref }}}+0.218\left(\frac{m}{m_{\text {ref }}}\right)^{2}, \\
\eta & =(1-\text { Reduction rate }) \eta_{\text {ref }}, \\
\eta_{\text {generation }} & =0.9+0.258 \text { load }-0.3 \text { load }^{2}+0.12 \text { load }^{3}
\end{aligned}
$$

The CSP model is established based on the literature [19] and is compared to SAM software simulation results. The annual power generation of the model is $66584.75 \mathrm{MWh}$, the plant electricity rate is assumed as $5 \%$; then, the actual power generation is $63255.5 \mathrm{MWh}$. The annual power generation of SAM is $61167.6 \mathrm{MWh}$, and the deviation of annual power generation is $3.3 \%$. The main reason is that this model is simplified that some of the error is ignored, making the model of the annual power generation higher.

\section{Methodology}

4.1. Operation Strategy. Operation strategies of the system can be divided into two modes: prioritize the PV (mode 1) and minimize the turbine shutdown (mode 2). Using mode 1 , the PV and the battery is prioritized over the CSP. That is to say that if the PV capacity is large enough to cover the load, it does and the CSP is shut down. The same can be said for the battery, if the battery discharge capacity is large enough to cover the load, it does and the CSP is shut down for the period that the battery discharges. This mode of operation will make the operation and maintenance costs of the system increase and the operating life decrease. However, the CSP must be shut down only if it remains offline for a sufficient amount of time. A turbine hot start can take as long as 1-2 hours. Therefore, in mode 2, the CSP plant will be shut down if it should be shut down for more than 2 hours.

The operation strategy was proposed by combining two modes and was shown in Figure 3 . Where $W_{\text {min,turb }}$ is the minimum output of turbine, $W_{\text {set }}$ is the rated output of the hybrid system, $W_{\mathrm{CSP}}$ and $W_{\mathrm{PV}}$ are the real output of CSP system and PV system, respectively, sto and BESS are the energy stored in the storage tank of CSP system and in the battery of PV system, respectively.

There are three operation modes according to the operation strategy.

(1) Energy of PV panels can meet energy demand and PV system runs alone. Exceeded energy is stored in a battery and the collected energy of CSP system is all stored in a storage tank

(2) Energy of PV panels cannot meet energy demand, and PV panels and battery are both used for energy generation. The collected energy of CSP system is all stored in a storage tank

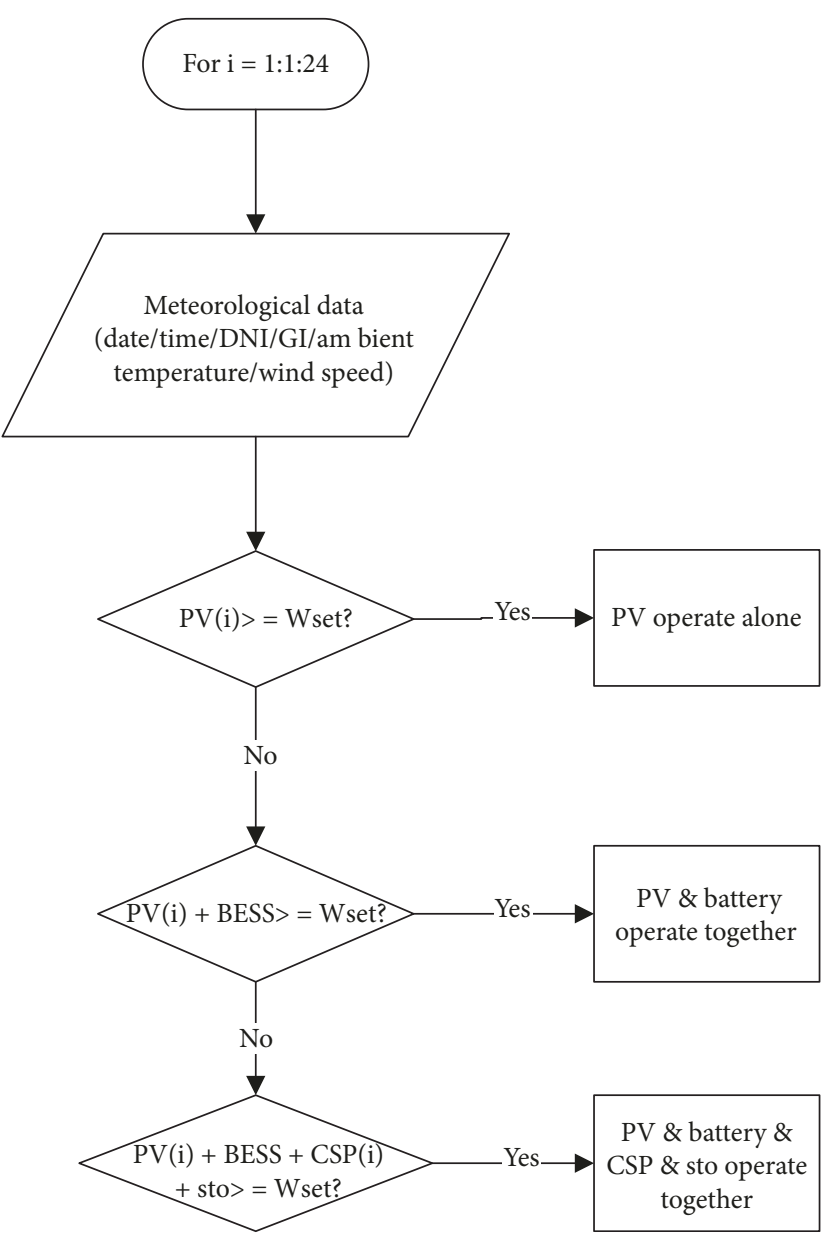

FIGURE 3: Operation strategy of CSP-PV hybrid power system.

(3) Energy of PV panels and battery cannot meet energy demand, and PV panels, battery, CSP system, and storage tank are all used for energy generation

4.2. Method of Optimization. Method of optimization adopted in this study is genetic algorithm. The classical optimization algorithm such as linear program and dynamic programming is easy to fall into the local optimal, and it is difficult to solve the global optimal problem. Genetic algorithm is a good way to overcome this shortcoming and is a global optimization algorithm with good convergence. Many scholars use genetic algorithms to optimize the system. The genetic algorithm is used to optimize the heat recovery system of the rotary kiln, and the mathematical relationship between the design parameters and the temperature and heat transfer rate of the heat recovery switch is deduced. The total heat transfer area and the total power consumption is reduced [27]. Gentils et al. optimized the support structure for offshore wind power, along the outer diameter and cross-sectional thickness of the support structure selected as the design variable. Optimizing makes the quality of the support structure reduced by $19.8 \%$ [28]. Li et al. used the reservoir as a decision variable to minimize the variance of the power output and maximize the annual power generation which is a goal by the NSGA-II [29]. 


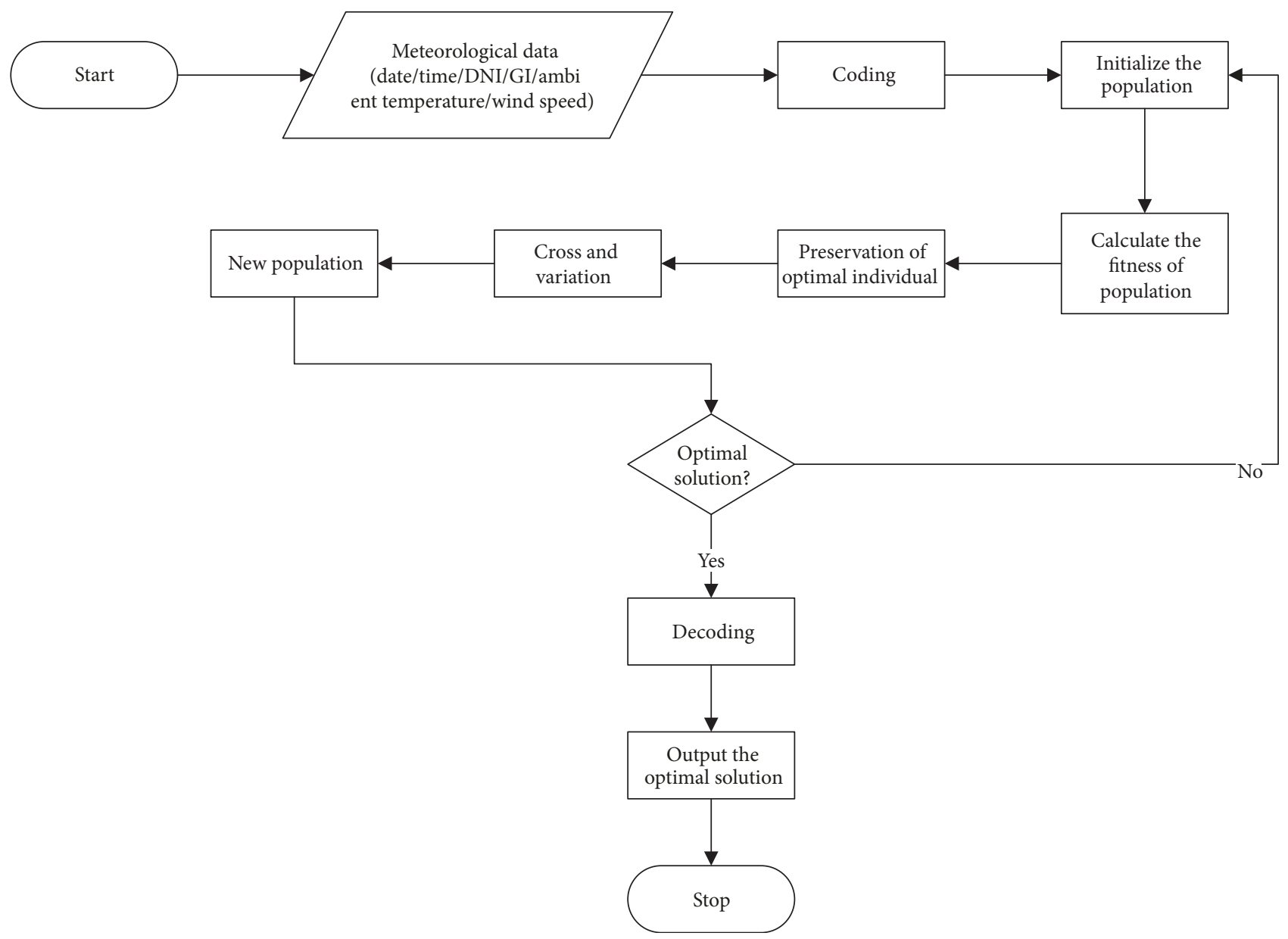

Figure 4: Process of genetic algorithm.

Genetic algorithm is an optimization method that simulated biological evolution. It is based on the principle of biological evolution and strategy of group optimization through iterative calculation of selection, replication, crossover, mutation, insertion, and migration. It is suitable for solving complex optimization problems [30]. The process of genetic algorithm is shown in Figure 4 .

The process of genetic algorithm is as follows:

(a) Randomly generate the initial population of the determined length

(b) Calculate the fitness value of the population iterations and produce the next generation of groups through replication, crossover, and mutation

(c) The best individual in each generation as the result of the implementation of the algorithm

(d) After a given genetic algebra, compare all the results of the implementation to obtain the optimal solution as an optimal process

The fitness function chosen in this paper is LCOE (levelized cost of energy). LCOE is calculated by equation (12)
[31]. Where $\mathrm{IC}_{\mathrm{CSP}}$ and $\mathrm{IC}_{\mathrm{PV}}$ are the initial investment of CSP power station and PV station, respectively, $\mathrm{AC}_{\mathrm{CSP}}$ and $\mathrm{AC}_{\mathrm{PV}}$ are the annual cost of CSP power station and PV station, respectively (operation and maintain cost is included), $E_{\mathrm{CSP}}$ and $E_{\mathrm{PV}}$ are the output power of CSP system and PV system in the first year, $d_{\mathrm{CSP}}$ and $d_{\mathrm{PV}}$ are annual decay rate of power generation, $i$ is the interest rate, and $N$ is the lifetime of the system.

$$
\mathrm{LCOE}=\frac{\mathrm{IC}_{\mathrm{CSP}}+\sum_{n=1}^{N}\left(\mathrm{AC}_{\mathrm{CSP}} /(1+i)^{n}\right)+\mathrm{IC}_{\mathrm{PV}}+\sum_{n=1}^{N}\left(\mathrm{AC}_{\mathrm{PV}} /(1+i)^{n}\right)}{\sum_{n=1}^{N}\left(\left(E_{\mathrm{CSP}}\left(1-d_{\mathrm{CSP}}\right)^{n}+E_{\mathrm{PV}}\left(1-d_{\mathrm{PV}}\right)^{n}\right) /(1+i)^{n}\right)},
$$

where $\mathrm{IC}_{\mathrm{CSP}}$ and $\mathrm{IC}_{\mathrm{PV}}$ can be divided into two parts: direct cost and indirect cost. The direct component is the investment associated with the power block $\left(C_{\mathrm{PB}}\right)$, solar field $\left(C_{\mathrm{SF}}\right)$, piping $\left(C_{\mathrm{PIP}}\right)$, storage system $\left(C_{\mathrm{TES}}\right)$, salt purchase $\left(C_{\mathrm{SALT}}\right)$, and balance of plant $\left(C_{\mathrm{CSP}, \mathrm{BoP}}\right)$. The indirect component covers all the remaining costs for the upfront investment that are not directly related to the equipment. These costs include the purchase of land $\left(C_{\text {LAND }}\right)$ and the engineering, procurement, and construction costs $\left(C_{\mathrm{EPC}}\right.$, 
TABLe 5: Cost estimation of the CSP plant and PV system.

\begin{tabular}{|c|c|c|c|}
\hline \multicolumn{2}{|l|}{ CSP direct cost } & \multicolumn{2}{|l|}{ CSP annual cost } \\
\hline Solar field cost $\left(C_{\mathrm{SF}}\right)$ & $240 \$ / \mathrm{m}^{2}$ of collector area & O\&M annual cost & $1.5 \%$ \\
\hline Piping cost $\left(C_{\mathrm{PIP}}\right)$ & $36 \$ / \mathrm{m}^{2}$ of collector area & Insurance annual cost & $0.5 \%$ \\
\hline Tank cost $\left(C_{\mathrm{TES}}\right)$ & $750 \$ / \mathrm{m}^{3}$ of storage volume & PV annual cost & \\
\hline $\mathrm{BoP}$ cost $\left(C_{\mathrm{CSP}, \mathrm{BoP}}\right)$ & $300 \$ / \mathrm{kW}_{\mathrm{e}}$ & $\mathrm{O} \& \mathrm{M}$ annual cost & $1.5 \%$ \\
\hline PV direct cost & & Insurance annual cost & $0.25 \%$ \\
\hline Panel cost $\left(C_{\mathrm{PV}}\right)$ & $1200 \$ / \mathrm{kW}_{\mathrm{p}}$ & $\mathrm{CSP} / \mathrm{PV}$ indirect cost & \\
\hline Inverter cost $\left(C_{\mathrm{INV}}\right)$ & $240 \$ / \mathrm{kW}$ & Land cost $\left(C_{\text {LAND }}\right)$ & $12 \$ / \mathrm{m}^{2}$ \\
\hline $\mathrm{BoP} \operatorname{cost}\left(C_{\mathrm{pv}, \mathrm{BoP}}\right)$ & $240 \$ / \mathrm{kW}$ & Engineering cost $\left(C_{\mathrm{EPC}}\right)$ & $20 \%$ \\
\hline Battery cost $\left(C_{\mathrm{B}}\right)$ & $1200 \$ / \mathrm{kWh}$ & Other assumption & \\
\hline PV degradation rate & $0.6 \%$ & Annual interest rate & $7 \%$ \\
\hline Operating lifetime & 25 years & CSP degradation rate & $0.2 \%$ \\
\hline
\end{tabular}

TABLE 6: Optimization design variables and range.

\begin{tabular}{lcc}
\hline Variable & Range & Unit \\
\hline Rated power of photovoltaic plant & $0-100$ & MW \\
Capacity of heat storage & $0-2000$ & MWh \\
Capacity of battery bank & $0-2000$ & MWh \\
\hline
\end{tabular}

calculated as a percentage of the direct costs). The equations for the direct and indirect initial costs of the CSP section are therefore given by

$$
\begin{aligned}
\mathrm{IC}_{\mathrm{CSP}}= & \mathrm{IC}_{\mathrm{CSP}, \mathrm{DIR}}+\mathrm{IC}_{\mathrm{CSP}, \mathrm{IND}}, \\
\mathrm{IC}_{\mathrm{PV}}= & \mathrm{IC}_{\mathrm{PV}, \mathrm{DIR}}+\mathrm{IC}_{\mathrm{PV}, \mathrm{IND}}, \\
\mathrm{IC}_{\mathrm{CSP}, \mathrm{DIR}}= & {\left[\left(C_{\mathrm{SF}}+C_{\mathrm{PIP}}\right) A_{\mathrm{SF}}+\left(C_{\mathrm{TES}}+C_{\mathrm{SALT}} \rho_{\mathrm{SALT}}\right) V_{\mathrm{TES}}\right] } \\
& +\left(C_{\mathrm{PB}}+C_{\mathrm{CSP}, \mathrm{BoP}}\right) P_{\mathrm{ORC}, \mathrm{nom}}, \\
\mathrm{IC}_{\mathrm{CSP}, \mathrm{IND}}= & C_{\mathrm{LAND}} A_{\mathrm{LAND}, \mathrm{CSP}}+\mathrm{IC}_{\mathrm{CSP}, \mathrm{DIR}} C_{\mathrm{EPC}}, \\
\mathrm{IC}_{\mathrm{PV}, \mathrm{DIR}}= & {\left[\left(C_{\mathrm{PV}}+C_{\mathrm{INV}}+C_{\mathrm{PV}, \mathrm{BoP}}\right) \mathrm{P}_{\mathrm{PV}, \mathrm{nom}}+C_{B} E_{B}\right], } \\
\mathrm{IC}_{\mathrm{PV}, \mathrm{IND}}= & C_{\mathrm{LAND}} A_{\mathrm{LAND}, \mathrm{PV}}+\mathrm{IC}_{\mathrm{PV}, \mathrm{DIR}} C_{\mathrm{EPC}} .
\end{aligned}
$$

The main economic data is shown in Table 5 [21]. The floor area of CSP power station and PV power station are estimated by literature [32]. The floor area of the PV station whose output is over $20 \mathrm{MW}$ and track by the fixed axis is 7.5 acres/MW, and the floor area of the CSP station is 10 acres/MW.

\section{Case Study}

The model is established in Matlab and it can simulate the operating performance of CSP-PV hybrid system. The output power of the CSP power station selected in this study is $30 \mathrm{MW}$. Input parameters are heat storage capacity, nominal power of PV station, and battery capacity, and output

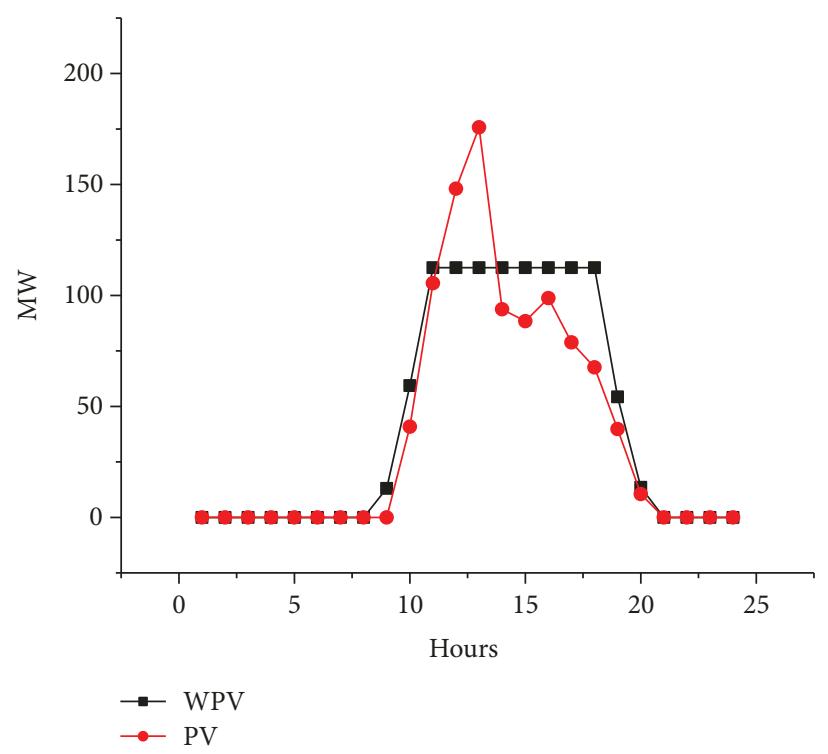

FIGURE 5: Comparison between the power generation capacity of PV system and the actual power generation on Equinox Day.

parameters are the output power of a hybrid system and LCOE. Then the model can simulate the daily, monthly, and annual performance of a hybrid system. The output power is $95 \%$ of the sum of the nominal power of the CSP and PV station. There is a 5\% unmet load demand [21].

The objective function of optimization is LCOE and variable and their range are shown in Table 6.

5.1. Optimization Based on a Typical Day. Optimization is based on the operation characteristics of Equinox Day. According to the results of genetic algorithm, when the installed capacity of the CSP power system is $30 \mathrm{MW}$, the LCOE of the CSP-PV hybrid system reaches the lowest which is $0.0660 \$ / \mathrm{kWh}$ under the condition that the rated power capacity of PV is $222.462 \mathrm{MW}$, the battery capacity is 14.687 MWh, and the heat storage capacity is $356.562 \mathrm{MWh}$. 


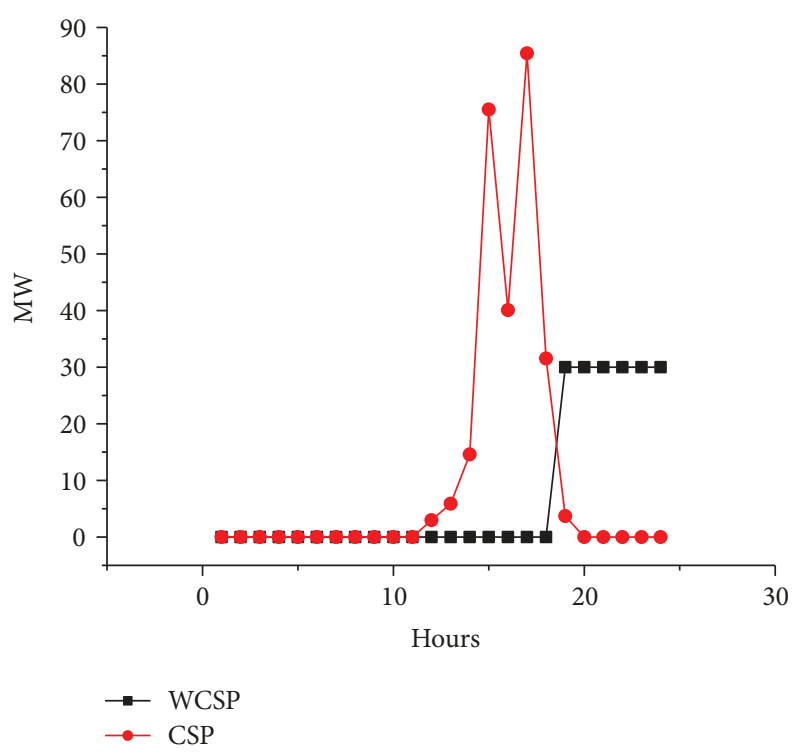

FIGURE 6: Comparison between the power generation capacity of CSP system and the actual power generation on Equinox Day.

Figures 5 and 6 show the comparison between the power generation capacity of $\mathrm{PV}$ and concentrated solar power (PV/ CSP) and the actual power generation (WPV/WCSP) in Equinox Day. The "PV" represents the power generated by the PV panels, and "WPV" represents the power output from the PV system after dispatch. The "CSP" represents the concentrated solar power energy, and it is stored in the TES. The "WCSP" is the actual power output from a solar thermal Rankine cycle. This is added in the manuscript. After the sun rises, the output power of the PV system increases as the irradiation intensity increases and reaches the maximum at 11 o'clock. The use of the battery makes the output power of the PV power plant does not change with the solar radiation changes, and the power generation curve tends to be gentle which makes the impact of PV system to reduce the power grid small and ensure that the system can still maintain the rated output power when the solar radiation is reduced. The CSP system generates power after 19 o'clock and maintains the rated power output. The use of the thermal storage system allows CSP system to continue to generate electricity after the sun goes down.

The system output power of Equinox Day is shown in Figure 7. After the sun rises, the output power of the PV system increases with the increase of solar radiation. The solar radiation intensity is the largest between 11:00 and 18:00, and the operating mode of the system is the power generated by the PV system alone; exceeded energy from the PV system is stored in the battery and the energy of CSP system is all stored in the heat storage tank. At 19 o'clock, the solar radiation is insufficient, the system operating mode changes from the PV alone into a PV system, the battery system and CSP system generate power at the same time, and the excess heat is stored in the thermal storage system. When at 20 o'clock, the sun is completely down without solar radiation, PV and CSP system has no energy source, then the system operating mode was changed into heat storage that generates power

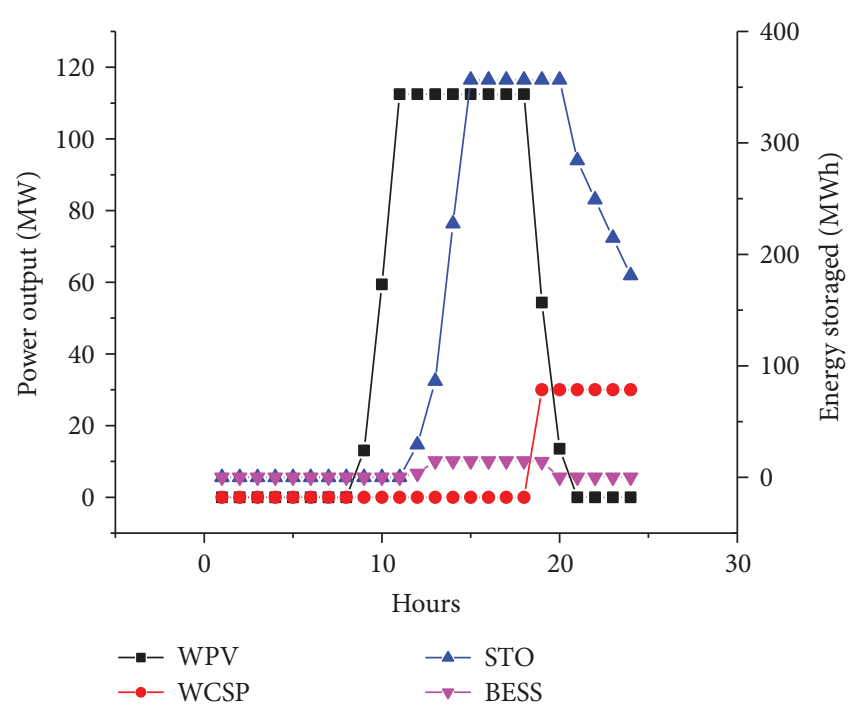

FIgURE 7: The system output power of Equinox Day of Equinox Day Optimization.

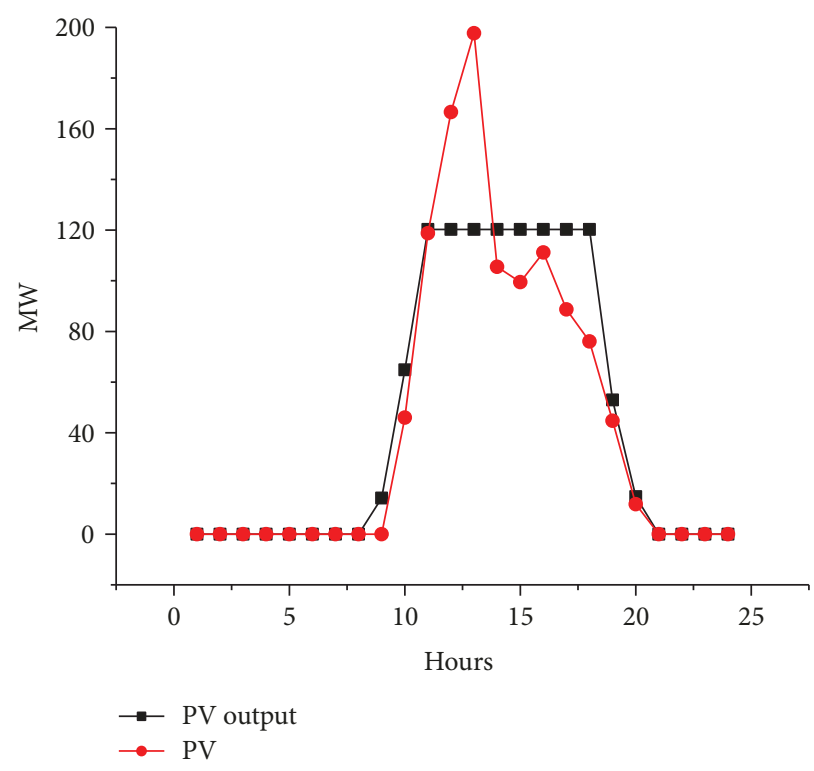

FIgURE 8: Comparison between the power generation capacity of PV system and the actual power generation on Equinox Day.

alone. In the system, the power of CSP is used to make up the power generation of the PV system, and the output power of CSP system varies with the PV output power. The more stable PV output power curve is makes the response of CSP system better. The use of heat storage in the CSP system allows the CSP system to continue to generate electricity after the sun goes down and to compensate for the lack of power generation in the PV system without solar radiation.

According to the calculation results, annual power generation of CSP-PV hybrid system is $368722 \mathrm{MWh}$. Where annual power generation of PV system is $288291 \mathrm{MWh}$, annual utilization hours are $3261 \mathrm{~h}$ which is higher than $\mathrm{PV}$-alone system. Annual power generation of CSP system 


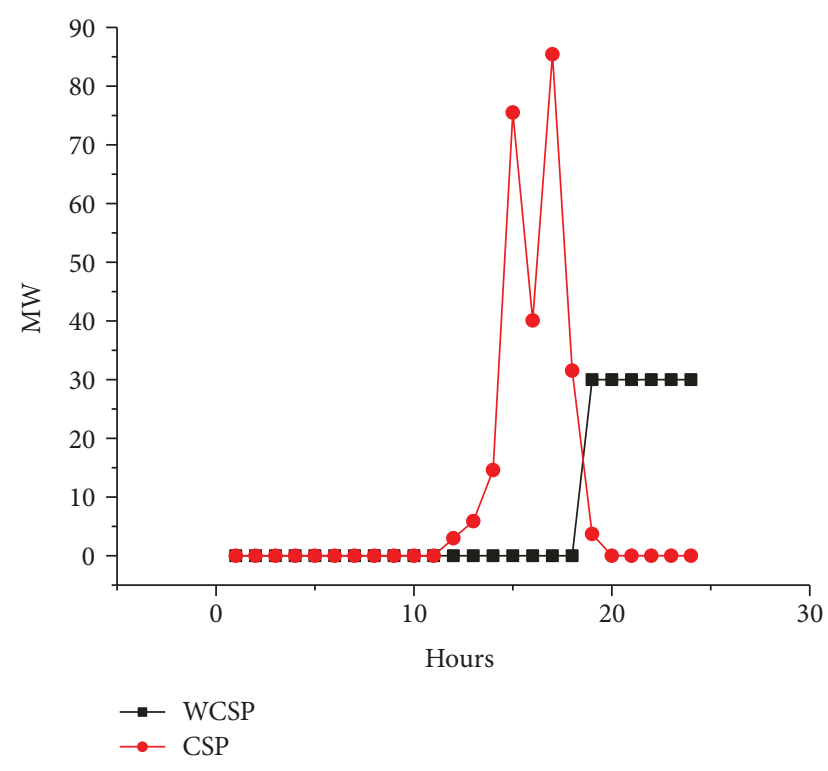

FIgURE 9: Comparison between the power generation capacity of CSP system and the actual power generation on Equinox Day.

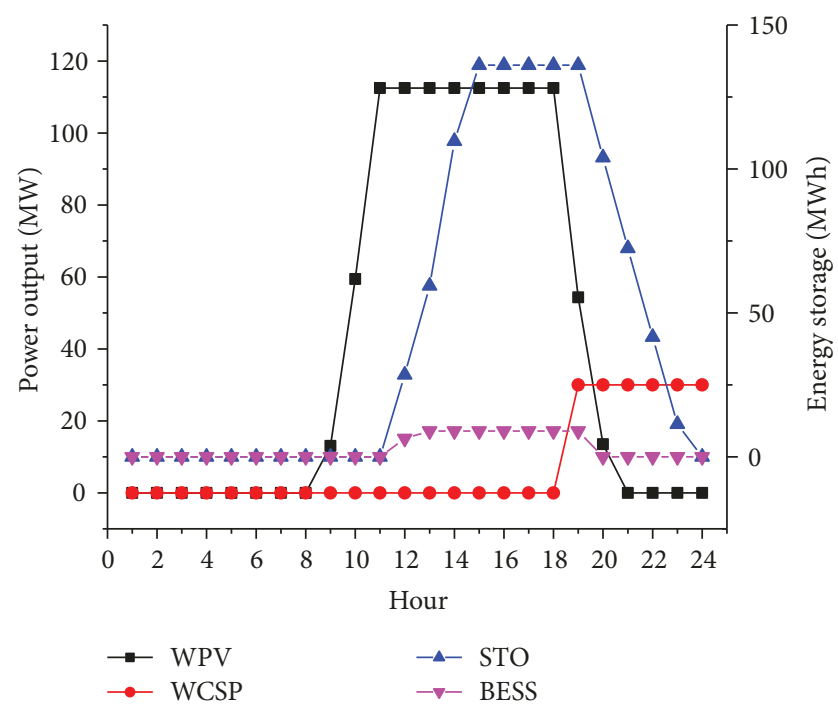

FIGURE 10: Output power of the system on Equinox Day of whole year optimization.

is $80431 \mathrm{MWh}$; annual utilization hours are $2681 \mathrm{~h}$ which is lower than the $280 \mathrm{MW}$ solar parabolic thermal power system in Solana; the reason is that the storage hour of Solana is 6 hours and the solar radiation is better. The optimized CSP-PV system combines the advantages of the PV power generation and CSP power generation system, which makes the annual operation hours of the PV system increase and the stability of the PV system operation improve, but the LCOE of the system is only $0.0660 \$ / \mathrm{KWh}$, which is lower than the CSP power generation alone.

5.2. Optimization Based on the Whole Year. GHI of Lhasa changes slowly with the seasons, and the DNI in summer
TABLE 7: Comparison between annual and day optimization.

\begin{tabular}{lcc}
\hline & $\begin{array}{c}\text { Optimized by } \\
\text { day operation }\end{array}$ & $\begin{array}{c}\text { Optimized by } \\
\text { annual operation }\end{array}$ \\
\hline $\begin{array}{l}\text { Annual output power } \\
\text { (MWh) }\end{array}$ & 368722 & 375695 \\
LCOE (\$/kWh) & 0.0660 & 0.0555 \\
CSP & & \\
$\begin{array}{l}\text { Capacity of heat storage } \\
\text { (MWh) }\end{array}$ & 356.562 & 136.059 \\
$\begin{array}{l}\text { Annual output power of } \\
\text { CSP system (MWh) }\end{array}$ & 80431 & 66659 \\
$\begin{array}{l}\text { Annual utilization hours of } \\
\text { CSP system (h) }\end{array}$ & 2681 & 2222 \\
$\begin{array}{l}\text { PV } \\
\text { Installed capacity of PV } \\
\text { system (MW) }\end{array}$ & $222.462 \mathrm{MW}$ & 242.954 \\
$\begin{array}{l}\text { Capacity of battery (MWh) } \\
\text { Annual output power of }\end{array}$ & 14.687 & 8.977 \\
$\begin{array}{l}\text { PV system (MWh) } \\
\text { Annual utilization hours of }\end{array}$ & 288291 & 309036 \\
PV system (h) & 3261 & 3201 \\
\hline
\end{tabular}

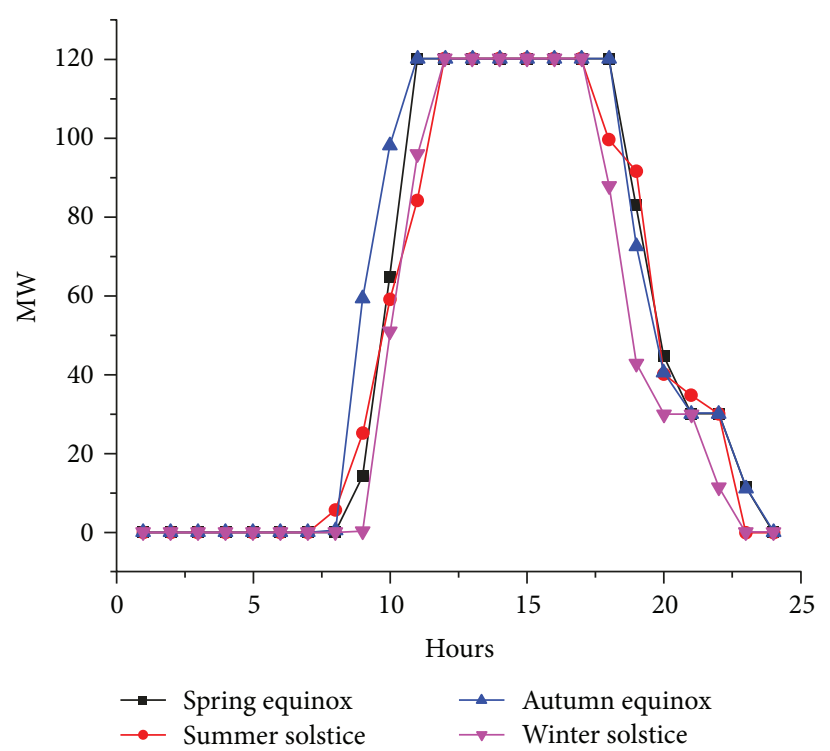

FIgURe 11: Comparative analysis of four typical days of whole year optimization.

and autumn is higher. To optimize the annual operating characteristics of the system based on the operation strategy proposed above. According to the results of genetic algorithm, when the installed capacity of the CSP power system is $30 \mathrm{MW}$, the LCOE of the CSP-PV hybrid system reaches the lowest which is $0.0555 \$ / \mathrm{kWh}$ under the condition that the rated power capacity of PV is $242.954 \mathrm{MW}$, the battery capacity is $8.977 \mathrm{MWh}$, and the heat storage capacity is $136.059 \mathrm{MWh}$. The LCOE is lower compared to 


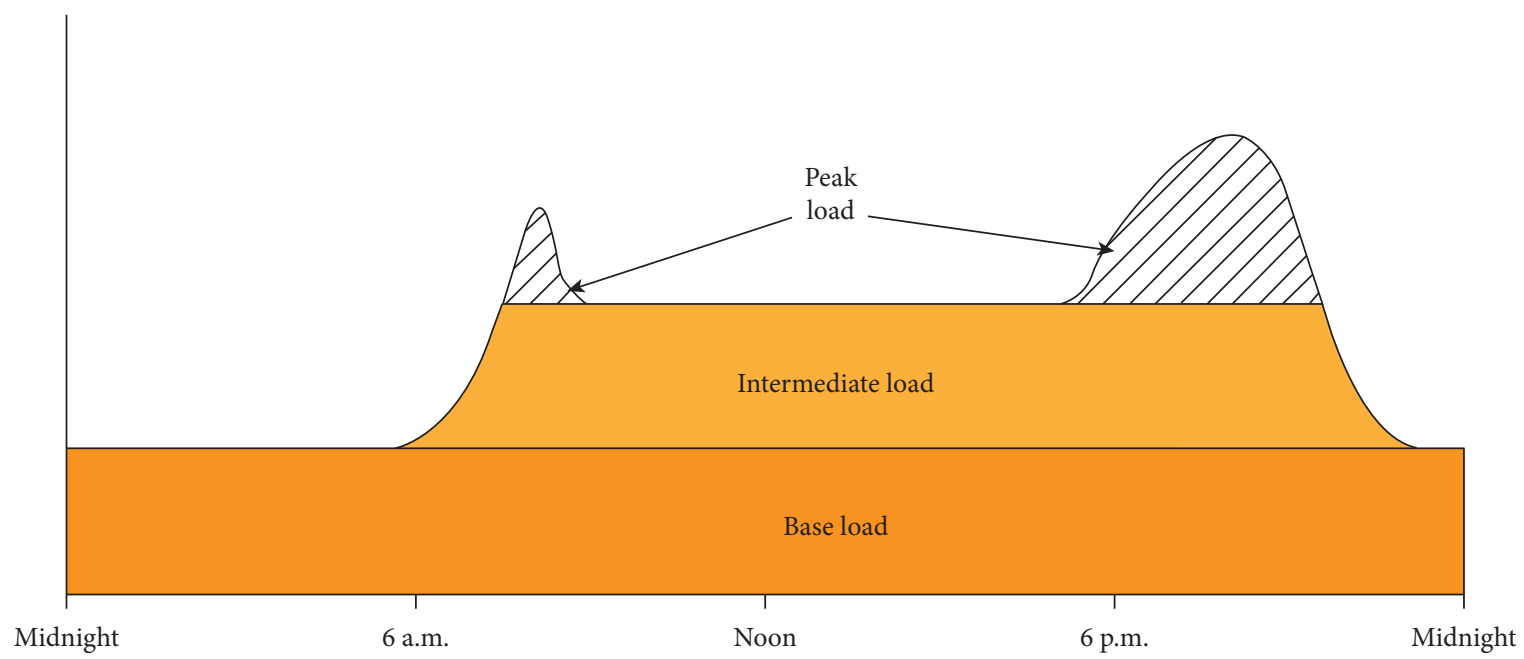

FiguRE 12: Electricity load curve.

TABLE 8: Impact of rated output power on CSP-PV system.

\begin{tabular}{|c|c|c|c|c|}
\hline & $85 \%$ & $90 \%$ & $95 \%$ & $100 \%$ \\
\hline Annual output power (MWh) & 328957 & 399050 & 375695 & 384810 \\
\hline LCOE $(\$ / k W h)$ & 0.0592 & 0.0561 & 0.0555 & 0.0530 \\
\hline \multicolumn{5}{|l|}{ CSP } \\
\hline Capacity of heat storage (MWh) & 145.613 & 254.971 & 136.059 & 166.577 \\
\hline Annual output power of CSP system (MWh) & 69925 & 80329 & 66659 & 74099 \\
\hline Annual utilization hours of CSP system (h) & 2331 & 2678 & 2222 & 2470 \\
\hline \multicolumn{5}{|l|}{ PV } \\
\hline Installed capacity of PV system (MW) & 78.423 & 99.805 & 242.954 & 97.555 \\
\hline Capacity of battery (MWh) & 10.061 & 11.274 & 8.977 & 5.752 \\
\hline Annual output power of PV system (MWh) & 259032 & 318721 & 309036 & 310711 \\
\hline Annual utilization hours of PV system (h) & 3303 & 3193 & 3201 & 3185 \\
\hline
\end{tabular}

the CSP power generation alone and lower compared to the $\mathrm{PV}$ power generation with battery which is to ensure stability of the power output of the system.

It can be found in Figures 8 and 9 from the comparative analysis of the power generation capacity and actual power generation that the output power of PV increases with the increase of solar radiation and reaches the rated output power at 11 o'clock when the system output power is no longer changing with the increase of solar radiation. After 14 o'clock, the solar radiation drops, the PV system still maintains the rated output power, and the application of the battery makes the output power fluctuation of the PV system lower. CSP system does not participate in the system power generation in the daytime and generates electricity after 19:00. Heat storage tank makes the CSP system ensure stable power generation when the sun goes down or no sun irradiation.

The output power of the system in Equinox Day is shown in Figure 10. After the sun rises, the storage tank begins to store energy and the battery stores the excess energy of the PV system. The operation mode of the system that PV operates alone from 11:00 to $18: 00$ and the exceeded energy is stored in a battery and heat storage tank. When at 19:00, the energy of the PV system is not enough to meet the energy needs, and the system operating mode is converted into the PV, battery, and CSP systems that operate at the same time. After 20:00, the sun has been down the mountain and the battery and the PV system cannot provide energy, then the power is provided by the heat storage tank.

According to the calculation results, annual power generation of the CSP-PV hybrid system is $375695 \mathrm{MWh}$. Where annual power generation of PV system is $309036 \mathrm{MWh}$, annual utilization hours are $3201 \mathrm{~h}$ which is higher than the $\mathrm{PV}$-alone system. Annual power generation of the CSP system is $66659 \mathrm{MWh}$; annual utilization hours are $2222 \mathrm{~h}$. It can be found that the use of CSP-PV hybrid system, which CSP system is to make up for the output power fluctuations of PV systems, can be combined with the advantages of both systems to increase annual operating hours of PV systems to reduce the rate of discards and decrease LCOE of the system but also can guarantee stable output. 


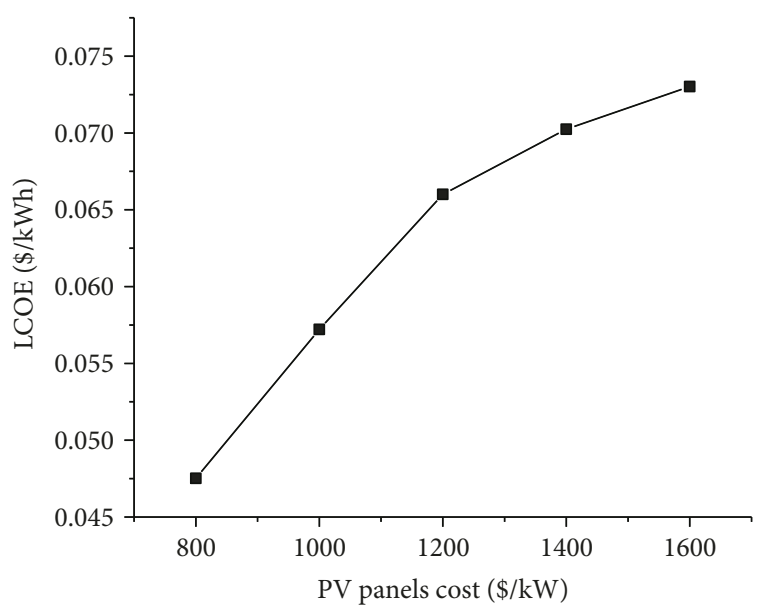

(a)

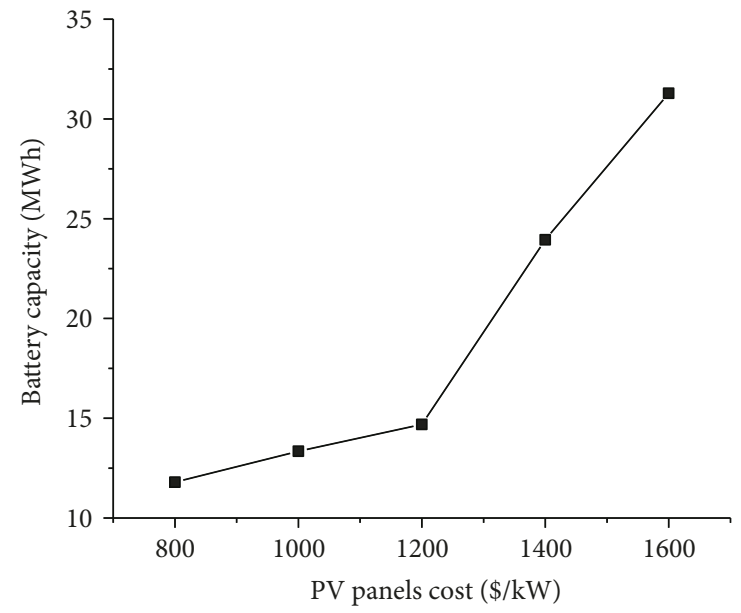

(c)

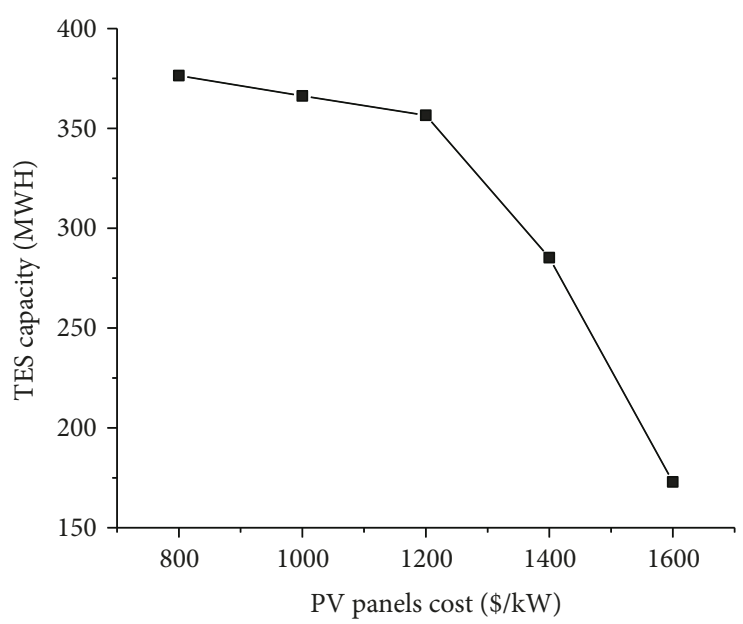

(b)

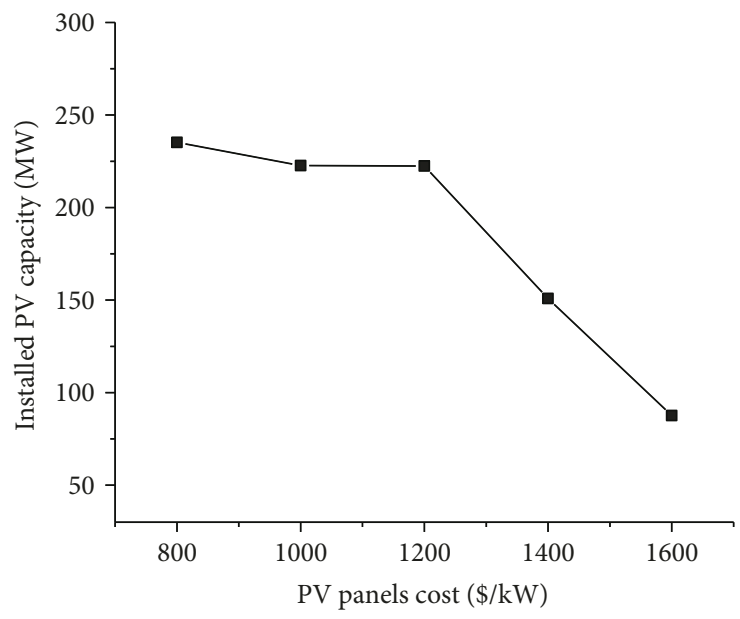

(d)

FIGURE 13: Influence of PV panels cost.

5.3. Discussion. The results of annual and day optimization are shown in Table 7. According to the comparison that can be found, the annual power generation of the system which is optimized by the annual operation characteristic is higher and the LCOE is lower. Annual utilization hours of PV and CSP system is lower due to the lower capacity of battery and heat storage tank which makes solar energy abandon more.

The comparative results of optimization of day and year which includes four typical days: Spring Equinox, Summer Solstice, Autumnal Equinox, and Winter Solstice are shown in Figure 11. It can be seen that the power generation curves of four typical days are basically the same. However, the power generation of Equinox Day is the worst because the solar radiation is poor, and Autumn Day is the best. Therefore, the system optimized with Equinox Day requires more energy storage system and more power generation, but LCOE is also higher in the meantime. The use of optimized CSP-PV system is to generate power at full load in the peak time. This system can be used for intermittent energy power generation compared to the load curve shown in Figure 12.

The estimated gross to net conversion factor, which means the ratio of on-grid electricity to the generated electricity, influences the results greatly. The estimated gross to net conversion factor is set to be from $85 \%$ to $100 \%$, and the results are shown in Table 8 .

As the estimated gross to net conversion factor increases, the annual output power and LCOE of the system are improved. When the annual operating characteristics are optimized, with the increase of the output power, LCOE of the system is reduced. The main reason is that the battery capacity is reduced. The impact of battery capacity on the system is great. The decrease in battery capacity has reduced the number of utilization hours of PV, but it has little effect.

5.4. Sensitivity Analysis. The influence of PV panels cost and the thermal storage cost based on the Spring Equinox are analyzed. The PV panels cost is varied from $800 \$ / \mathrm{kW}$ to 


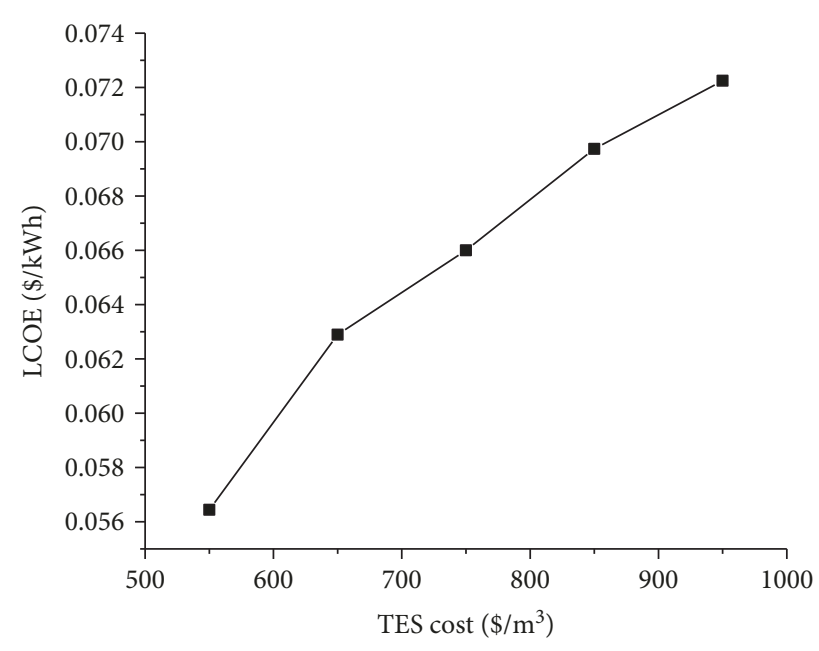

(a)

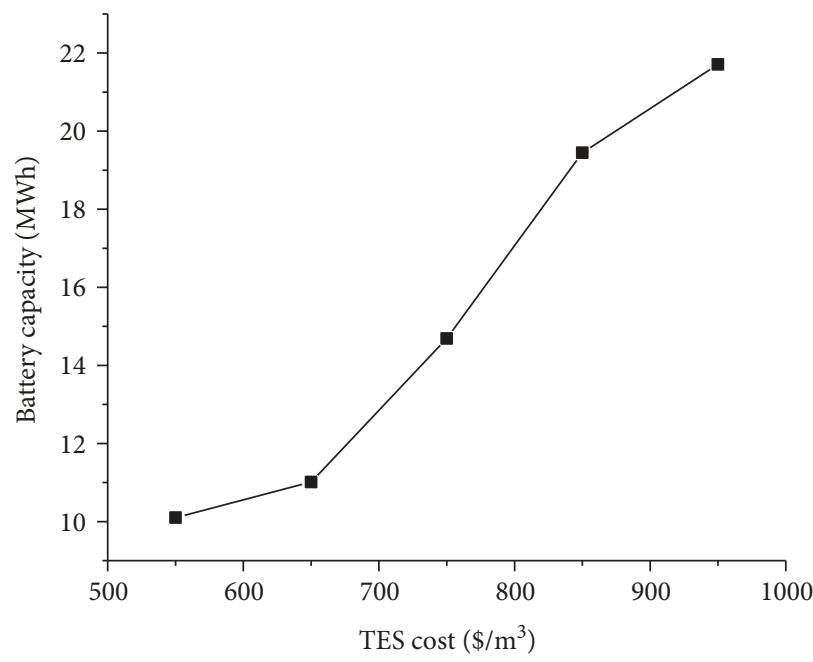

(c)

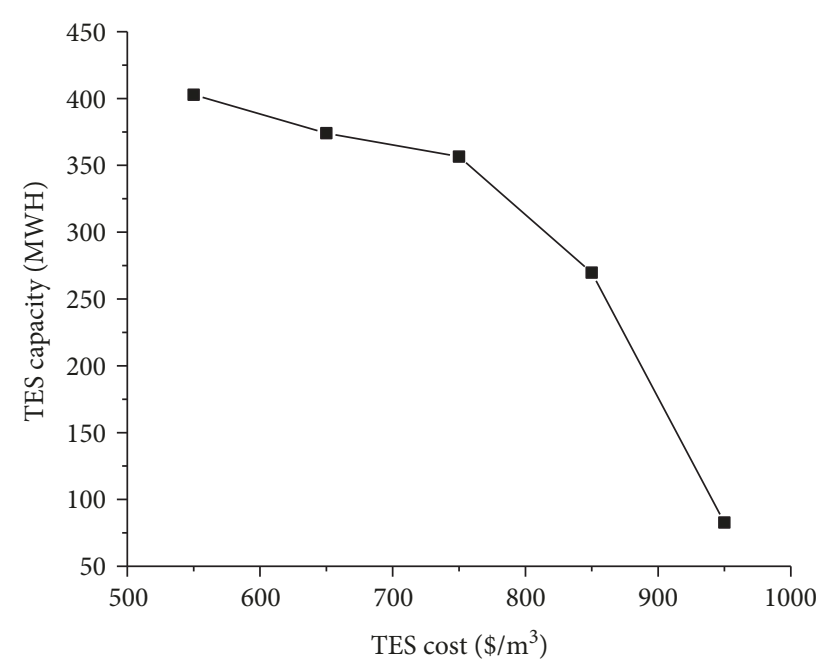

(b)

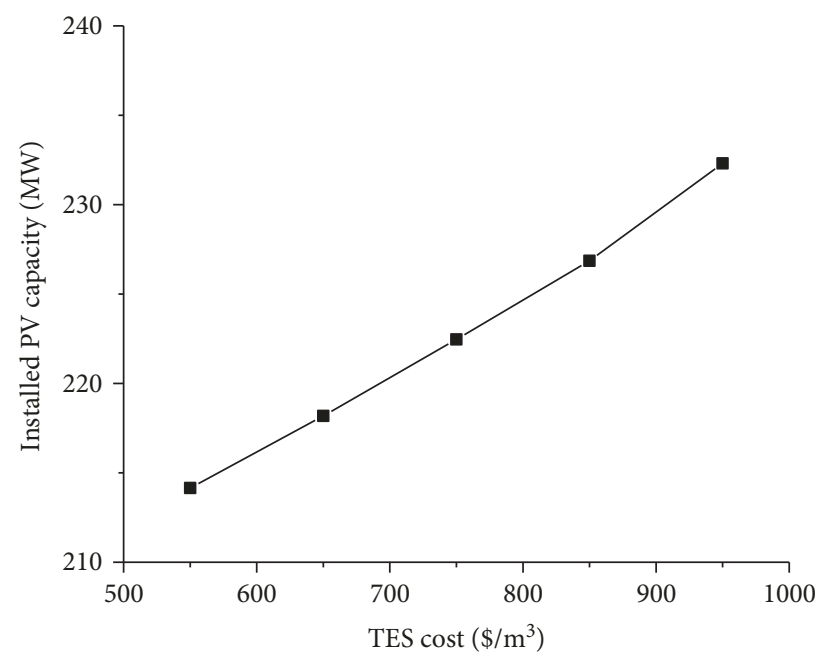

(d)

Figure 14: Influence of TES cost.

$1600 \$ / \mathrm{kW}$, and the thermal storage cost varied from $550 \$ /$ $\mathrm{m}^{3}$ to $950 \$ / \mathrm{m}^{3}$. The results are shown in Figures 13 and 14 .

\section{Conclusion}

In this paper, the operation strategy of CSP-PV hybrid system is proposed. Based on this operation strategy, the ratio of PV and CSP in the system is optimized by genetic algorithm, which makes LCOE of the system to a minimum. Through the calculation of this paper, it is found that the increase of PV capacity in the CSP-PV system can reduce the power generation cost of the system; the cost of the battery is high and when the use of batteries will greatly improve the power generation cost of the system; the introduction of the CSP system makes it easy to ensure the stability of the output power of the system in the case of small battery capacity, which greatly improves the annual utilization of the PV and reduces the number of solar discard, but to a certain extent, the utilization efficiency of the CSP system is reduced; the integration of PV and CSP system not only can reduce the power generation cost of CSP system but also can ensure the stability of the output of PV system.

When the output power is set to $95 \%$ of the sum of the PV-rated output power and the CSP-rated output power, the system is optimized by the operation characteristics of Spring Equinox and the result is as follows: the lowest LCOE is $0.0660 \$ / \mathrm{kWh}$, the capacity of PV and CSP system are $222.462 \mathrm{MW}$ and $30 \mathrm{MW}$, respectively, and the capacity of heat storage and battery are 356.562 MWh and 14.687 MWh. According to the calculation results, annual power generation of the CSP-PV hybrid system is $368722 \mathrm{MW}$. Where the annual power generation of PV system is $288291 \mathrm{MW}$, annual utilization hours are $3261 \mathrm{~h}$, and annual power generation of CSP system is $80431 \mathrm{MW}$, annual utilization hours are $2681 \mathrm{~h}$.

When the system is optimized by the operation characteristics of the whole year, the result is that the lowest LCOE is $0.0555 \$ / \mathrm{kWh}$, the capacity of PV and CSP system are 242.954 MW and 30 MW, respectively, and the capacity of heat storage and battery are 136.059 MWh and 8.977 MWh. 
According to the calculation results, annual power generation of PV system is $309036 \mathrm{MW}$, annual utilization hours are $3201 \mathrm{~h}$, and annual power generation of the CSP system is $66659 \mathrm{MW}$, annual utilization hours are $2222 \mathrm{~h}$.

The comparison shows that the power generation curves of the hybrid system are similar in the two optimization methods, but LCOE is lower when optimized by the annual operation characteristic, and the annual utilization rate of the system is higher when optimized by Spring Equinox.

The use of optimized CSP-PV hybrid system, which CSP system is to make up for the output power fluctuations of PV systems, can be combined with the advantages of both systems to increase annual operating hours of PV systems to reduce the rate of discards and decrease LCOE of the system but also can guarantee stable output. The operation strategy proposed in this paper provides a new idea for the operation of CSP-PV hybrid power generation system. The optimization method can be used in the preliminary design of power station.

\section{Nomenclature}

\begin{tabular}{|c|c|}
\hline PV: & Photovoltaic \\
\hline CSP: & Concentrated solar power \\
\hline LCOE: & Levelized cost of energy \\
\hline DC: & Direct current \\
\hline AC: & Alternating current \\
\hline MPPT: & Maximum power point tracking \\
\hline DNI: & Direct normal irradiation \\
\hline GHI: & Global horizontal irradiance \\
\hline$T_{C}:$ & Operating temperature of PV panels \\
\hline$T_{A}:$ & Ambient temperature \\
\hline$U_{L}:$ & Actual heat transfer factor \\
\hline$U_{L, \mathrm{NOCT}}:$ & Rated heat transfer factor \\
\hline$\eta_{\mathrm{PV}}:$ & Actual PV panel efficiency \\
\hline$\tau \alpha:$ & Transfer absorption factor \\
\hline$\gamma:$ & Temperature factor \\
\hline$T_{C, \mathrm{REF}}:$ & $\begin{array}{l}\text { PV module temperature under standard test } \\
\text { conditions }\end{array}$ \\
\hline$n_{\mathrm{MOD}}:$ & Number of PV subarray \\
\hline$A_{\mathrm{MOD}}:$ & Active area of each PV module \\
\hline$\eta_{\mathrm{INV}}:$ & Inverter efficiency \\
\hline$f_{\mathrm{PV}}:$ & Derating factor \\
\hline$\eta_{\mathrm{BC}}:$ & Battery efficiencies during charge processes \\
\hline$\eta_{\mathrm{BD}}:$ & Battery efficiencies during discharge processes \\
\hline SOC: & State of charge \\
\hline DOD: & Depth-of-discharge \\
\hline$T_{\mathrm{i}}:$ & Inlet temperature of the heat transfer oil \\
\hline$T_{\mathrm{O}}:$ & Outlet temperature of the heat transfer oil \\
\hline$\Delta T:$ & $\begin{array}{l}\text { Temperature difference between the average } \\
\text { temperature of the collector field and the ambient } \\
\text { temperature }\end{array}$ \\
\hline$W_{\text {min,turb }}:$ & Minimum output of turbine \\
\hline$W_{\text {set }}:$ & Rated output of the hybrid system \\
\hline$W_{\mathrm{CSP}}:$ & Real output of CSP system \\
\hline$W_{\mathrm{PV}}:$ & Real output of PV system \\
\hline BESS: & Battery Energy Storage System \\
\hline $\mathrm{IC}_{\mathrm{CSP}}:$ & Initial investment of CSP power station \\
\hline
\end{tabular}

$\mathrm{IC}_{\mathrm{PV}}$ : Initial investment of $\mathrm{PV}$ power station

$\mathrm{AC}_{\mathrm{CSP}}$ : Annual cost of CSP power station

$\mathrm{AC}_{\mathrm{PV}}$ : Annual cost of $\mathrm{PV}$ power station

$E_{\mathrm{CSP}}: \quad$ Output power of CSP system

$E_{\mathrm{PV}}: \quad$ Output power of $\mathrm{PV}$ system

$d_{\mathrm{CSP}}: \quad$ Annual decay rate of CSP power generation

$d_{\mathrm{PV}}$ : Annual decay rate of PV power generation

$i$ : $\quad$ Interest rate

$N$ : $\quad$ Lifetime of system

O\&M: Operation and maintain.

\section{Data Availability}

The data used to support the findings of this study are available from the corresponding author upon request.

\section{Conflicts of Interest}

The authors declare that they have no conflicts of interest.

\section{Acknowledgments}

The research work is supported by the National Major Fundamental Research Program of China (No. 2015CB251505) and the Fundamental Research Funds for the Central Universities (2018ZD04, 2016YQ04).

\section{References}

[1] Agency, International Energy, World Energy Outlook 2013, IEA, Paris, 2013.

[2] J. Spelling, Solar Power Technologies - Solar Fundamentals, KTH, Stockholm, 2012.

[3] H. Ibrahim, A. Ilinca, and J. Perron, "Energy storage systems-characteristics and comparisons," Renewable and Sustainable Energy Reviews, vol. 12, no. 5, pp. 1221-1250, 2008.

[4] M. Huber, D. Dimkova, and T. Hamacher, "Integration of wind and solar power in Europe: assessment of flexibility requirements," Energy, vol. 69, pp. 236-246, 2014.

[5] U. Desideri, F. Zepparelli, V. Morettini, and E. Garroni, "Comparative analysis of concentrating solar power and photovoltaic technologies: technical and environmental evaluations," Applied Energy, vol. 102, pp. 765-784, 2013.

[6] Technology Roadmap, Solar Photovoltaic Energy, International Energy Agency, Paris, 2014.

[7] IEA, Solar Energy Perspectives, IEA, Paris, 2011.

[8] Technology Roadmap, Solar Thermal Energy, International Energy Agency, Paris, 2014.

[9] C. Parrado, A. Girard, F. Simon, and E. Fuentealba, "2050 LCOE (Levelized Cost of Energy) projection for a hybrid PV (photovoltaic)-CSP (concentrated solar power) plant in the Atacama Desert, Chile," Energy, vol. 94, pp. 422-430, 2016,.

[10] F. Dominio, Techno-Economic Analysis of Hybrid PV-CSP Power Plants: Advantages and disadvantages of intermediate and peak load operation, Universitat Politècnica de Catalunya, 2014.

[11] D. Cocco, L. Migliari, and M. Petrollese, "A hybrid CSP-CPV system for improving the dispatchability of solar power plants," Energy Conversion and Management, vol. 114, pp. 312-323, 2016. 
[12] G. Cau, D. Cocco, and M. Petrollese, "Optimal energy management strategy for CSP-CPV integrated power plants with energy storage," in Proceedings of the 28th International Conference on Efficiency, Cost, Optimization, Simulation and Environmental Impact of Energy Systems, Pau, France, 2015.

[13] A. Green, C. Diep, R. Dunn, and J. Dent, "High capacity factor CSP-PV hybrid systems," Energy Procedia, vol. 69, pp. 20492059, 2015.

[14] M. Hlusiak, M. Götz, and H. A. B. Díaz, "Hybrid photovoltaic (PV)-concentrated solar thermal power (CSP) power plants: modelling, simulation and economics," in Proceedings of the 29th European Photovoltaic Solar Energy Conference and Exhibition, Amsterdam, Netherlands, September 2014.

[15] J. P. N. Bootello, S. V. Rubia, L. S. Gallar, and L. F. CAlderon, "Manageable hybrid plant using photovoltaic and solar thermal technology and associated operating method," 2015, U.S. Patent 9140241B.

[16] K. Larchet, Solar PV-CSP Hybridisation for Baseload Generation: A Techno-economic Analysis for the Chilean Market, 2015.

[17] L. R. Castillo Ochoa, "Techno-economic analysis of combined hybrid concentrating solar and photovoltaic power plants: a case study for optimizing solar energy integration into the South African electricity grid," 2014.

[18] "Mathworks," June 2018, https://ww2.mathworks.cn.

[19] "System Advisor Model (SAM)," June 2018, https://sam.nrel .gov/.

[20] "Weather data of System Advisor Model," August 2017, https://sam.nrel.gov/weather/.

[21] M. Petrollese and D. Cocco, "Optimal design of a hybrid CSPPV plant for achieving the full dispatchability of solar energy power plants," Solar Energy, vol. 137, pp. 477-489, 2016.

[22] A. M. Patnode, Simulation and performance evaluation of parabolic trough solar power plants, University of WisconsinMadison, 2006.

[23] S. Shijin, Simulation and Calculation of Trough Solar Thermal Power Generation, Inner Mongolia University of Technology, 2014.

[24] H. Suyi and H. Shuhong, Principle and Technology of Solar Thermal Power Generation, vol. 204, China Electric Power Press, Beijing, 2012.

[25] R. L. Bartlett, Steam Turbine Performance and Economics, McGraw-Hill, New York, 1958.

[26] R. Messenger, J. Ventre, and T. R. Mancini, "Solar electric systems," in The Engineering Handbook, CRC Press, Second edition, 2004.

[27] Q. Yin, W. J. Du, and L. Cheng, "Optimization design of heat recovery systems on rotary kilns using genetic algorithms," Applied Energy, vol. 202, pp. 153-168, 2017.

[28] T. Gentils, L. Wang, and A. Kolios, "Integrated structural optimisation of offshore wind turbine support structures based on finite element analysis and genetic algorithm," Applied Energy, vol. 199, pp. 187-204, 2017.

[29] F. F. Li and J. Qiu, "Multi-objective optimization for integrated hydro-photovoltaic power system," Applied Energy, vol. 167, pp. 377-384, 2016.

[30] G. B. Leyland, "Multi-objective optimisation applied to industrial energy problems," in Section De Génie Mécanique Pour L'obtention Du Grade De Docteur Ės Sciences Techniques par Master of Engineering in Mechanical Engineering, University of Auckland, 2002.
[31] A. R. Starke, J. M. Cardemil, R. A. Escobar, and S. Colle, "Assessing the performance of hybrid CSP+ PV plants in northern Chile," Solar Energy, vol. 138, pp. 88-97, 2016.

[32] S. Ong, C. Campbell, P. Denholm, R. Margolis, and G. Heath, Land-Use Requirements for Solar Power Plants in the United States, vol. 140, National Renewable Energy Laboratory, Golden, CO, USA, 2013. 

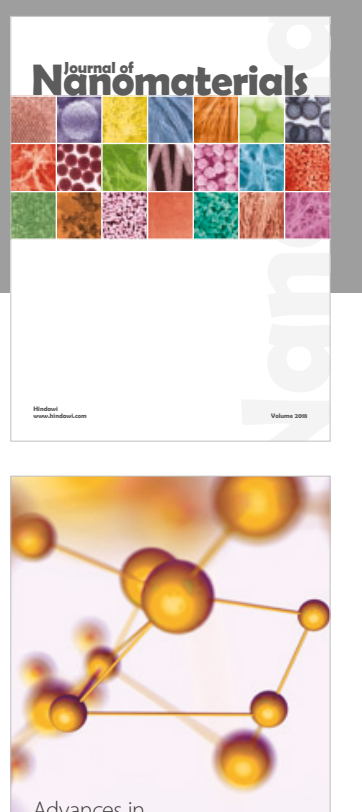

Physical Chemistry
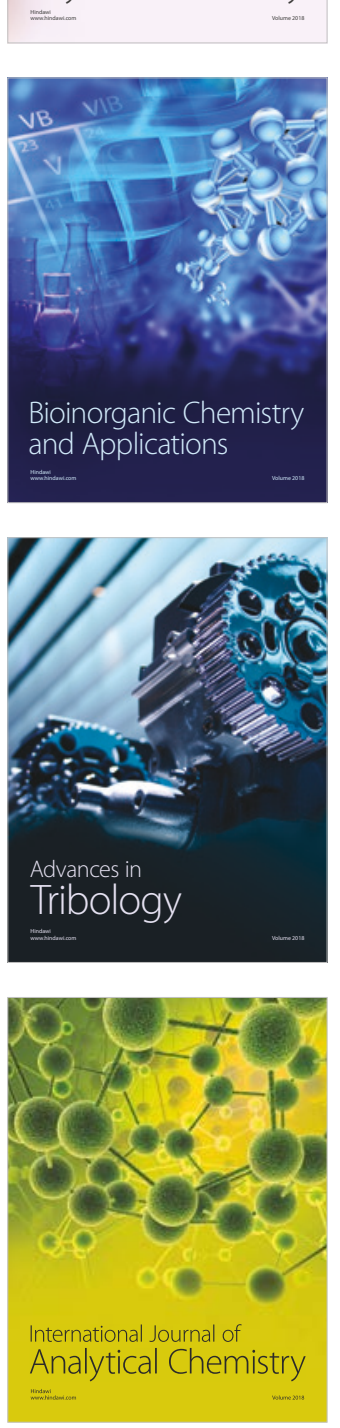

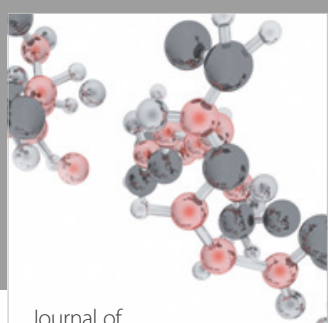

Analytical Methods

in Chemistry

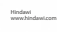

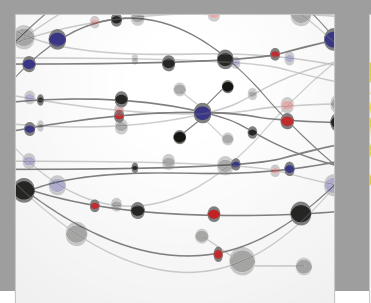

The Scientific World Journal

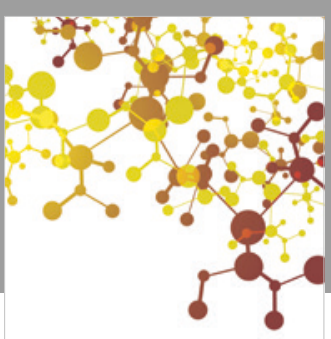

Journal of

Applied Chemistry
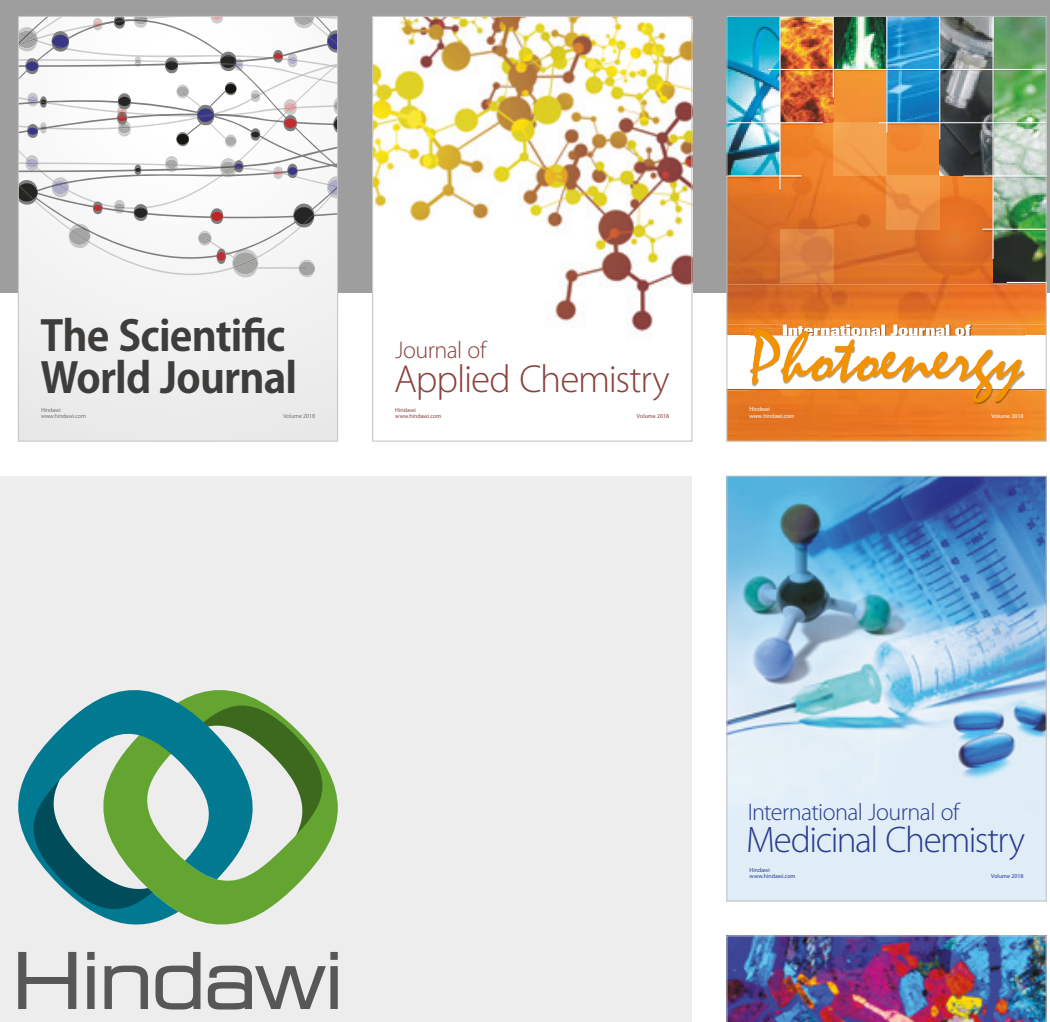

Submit your manuscripts at

www.hindawi.com
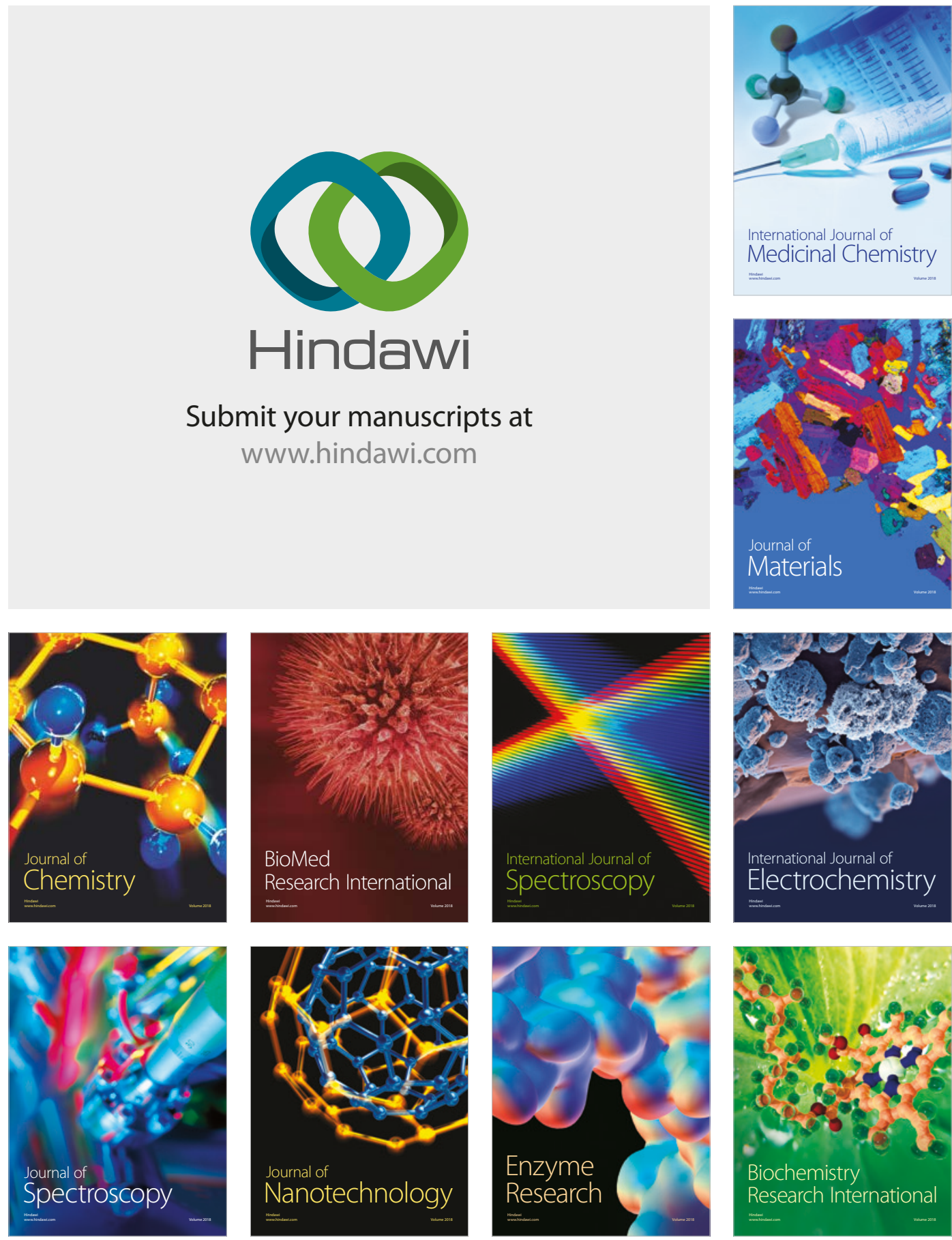
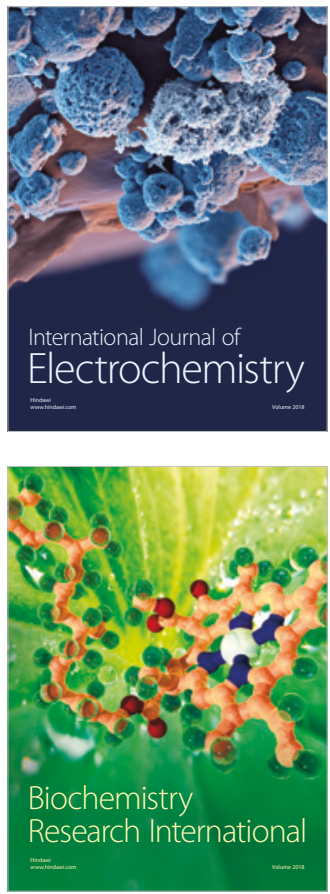